\title{
Multinational enterprise regional management centres: Characteristics and performance
}

Chakravarty, D., Hsieh, Y-Y., Schotter, A. P. J., \& Beamish, P. W. (2017). Multinational enterprise regional management centres: Characteristics and performance. Journal of World Business, 52(2), $296-311$. https://doi.org/10.1016/j.jwb.2016.12.011

Link to publication record in Ulster University Research Portal

\section{Published in:}

Journal of World Business

Publication Status:

Published (in print/issue): 01/02/2017

DOI:

10.1016/j.jwb.2016.12.011

\section{Document Version}

Author Accepted version

\section{General rights}

Copyright for the publications made accessible via Ulster University's Research Portal is retained by the author(s) and / or other copyright owners and it is a condition of accessing these publications that users recognise and abide by the legal requirements associated with these rights.

\section{Take down policy}

The Research Portal is Ulster University's institutional repository that provides access to Ulster's research outputs. Every effort has been made to ensure that content in the Research Portal does not infringe any person's rights, or applicable UK laws. If you discover content in the Research Portal that you believe breaches copyright or violates any law, please contact pure-support@ulster.ac.uk. 
Multinational Enterprise Regional Management Centres: Characteristics and Performance

\author{
Dwarka Chakravarty \\ Ivey Business School \\ Western University \\ 1255 Western Road \\ London, Ontario, N6G 0N1, Canada \\ Tel: +1 (519) 6613038 \\ dchakravarty.phd@ivey.ca
}

$\&$

Ying-Ying Hsieh

Ivey Business School

Western University

1255 Western Road

London, Ontario, N6G 0N1, Canada

Tel: +1 (519) 6610244

yhsieh.phd@ivey.ca

\&

Andreas P.J. Schotter*

Ivey Business School

Western University

1255 Western Road

London, Ontario, N6G 0N1, Canada

Tel: +1 (519) 6613038

aschotter@ivey.uwo.ca

\&

\title{
Paul W. Beamish
}

Ivey Business School

Western University

1255 Western Road

London, Ontario, N6G 0N1, Canada

Tel: +1 (519) 6613237

pbeamish@ivey.uwo.ca

* Corresponding author 


\title{
Multinational Enterprise Regional Management Centres: Characteristics and Performance
}

\begin{abstract}
In multinational enterprises (MNEs), regional management centres (RMCs) most frequently take the form of either dedicated regional headquarters (RHQs) or regional management mandates (RMMs) assigned to operating subsidiaries. We identify a series of critical differences in characteristics and performance between RHQs and RMMs, using a longitudinal sample of 855 Japanese RMCs across 41 countries. We also investigate parent-level differences between MNEs with distinct RMC configurations. We propose a structural complement to regional strategy extensions of the integration-responsiveness framework, and provide an important large sample baseline, aiding new theoretical and empirical research into MNE regional management strategy and structure.
\end{abstract}

Keywords: MNE evolution; multinational enterprise; regional headquarters; regional management centres; theory of the MNE; regionalization 


\section{Multinational Enterprise Regional Management Centres: Characteristics and Performance INTRODUCTION}

The idea that regionalization may better describe multinational enterprise (MNE) internationalization than global integration or multi-domesticity (Rugman \& Verbeke, 2004), has led to renewed academic interest in regional strategies and structures, which can help balance global integration and local responsiveness (Prahalad \& Doz, 1987). Most of the research on regional management structures (e.g., Ambos \& Schlegelmilch, 2010; Hoenen, Nell, \& Ambos, 2014; Lunnan \& Zhao, 2014) has focused on regional headquarters (RHQs). An RHQ is a special type of MNE foreign affiliate, tasked with the coordination, control, development and/or implementation of business strategies in a specific region (Enright, 2005a). The use of RHQs by MNEs leads to a three-tier nested structure (Hoenen \& Kostova, 2014), with regular subsidiaries reporting to RHQs and RHQs reporting to corporate headquarters (HQ).

In a number of MNEs, HQ functions may be regionally distributed to specialized administrative units (RHQs), and/or to operating subsidiaries which are mandated to allocate some time and resources to performing HQ functions (Alfoldi, Clegg, \& McGaughey 2012; Piekkari, Nell, \& Ghauri, 2010; Schütte, 1997; Verbeke \& Asmussen, 2016). Consistent with Alfoldi et al., (2012), we use the term Regional Management Mandates (RMMs) for the latter, and use the term Regional Management Centres (RMCs) to collectively describe RHQs and RMMs.

There is evidence suggesting that a focus on RHQs has led to a neglect of research on other types of regional management units such as RMMs (Alfoldi et al., 2012). Apart from a few studies such as Laserre (1996), Enright et al., (2005a, b) and Alfoldi et al., (2012), there is very little research on the nature and characteristics of diverse units performing HQ functions at a regional level. Instead, most regional management research has focused on RHQ roles, evolution, and locations (e.g., Asakawa \& Lehrer, 2003; Piekkari et al., 2010; Yeung, Poon, \& Perry, 2001) Hence, there is a need to investigate regional structural elements beyond RHQs with regards to their relative prevalence, different characteristics, establishment logics, evolution, and simultaneous usage. 
Additionally, literature suggests that of the few studies examining RMC characteristics, apart from exceptions such as Enright (2005a, b), large scale empirical studies are scarce (Alfoldi et al., 2012). An extensive search for RMC studies across the major international business and strategy literatures ${ }^{\mathrm{i}}$ yielded only 30 papers, largely focused on RHQs (see Appendix I). Most of these studies are based on small sample sizes, restricted to one particular region, or are descriptive single-company case studies with limited generalizability.

Hence, the extant literature lacks both scope and scale in regard to examining diversity within RMCs and characteristics of these diverse units. Accordingly, we develop a three-part research question to guide our exploratory investigation:

1) How do RMCs (RMMs and RHQs) differ in their characteristics and performance?

2) How do characteristics and performance differ between MNEs deploying different RMC configurations?

3) How do characteristics of RMCs, and of MNEs with RMCs evolve over time?

We aim to make two contributions. First, based on our findings, we provide a structural complement to Verbeke and Asmussen’s (2016) regional strategy extension of the integrationresponsiveness framework (Bartlett \& Ghoshal, 1989); and develop four related propositions. Second, our results provide an important large sample baseline to inform subsequent theory building and empirical research into MNE regional management strategy and structure.

\section{Background}

Regional Management Rationale. Balancing conflicting demands for global integration and local responsiveness (Prahalad \& Doz, 1987) remains an important challenge for MNEs. Regional management structures offer a feasible trade-off when operations within a region are large, complex, and different from other regions, providing opportunities for regional level scale economies and responsiveness (Egelhoff, 1982; Verbeke \& Asmussen, 2016). Stopford and Wells (1972) was one of the earliest contingency studies to associate MNE regional structures with strategy implementation. They discussed how MNEs 
with a high percentage of foreign sales adopted regional (area) management structures, and how global product divisions were preferred when product diversity was high. Egelhoff (1988) tested the Stopford and Wells (1972) hypothesis. His results suggested that higher levels of foreign manufacturing rather than foreign sales led to regional management structures (due to co-ordination required for optimizing regional sourcing strategies). Using a sample of 95 German firms, Wolf \& Egelhoff (2002) re-tested and found support for Egelhoff's (1988) model, and extended it by considering strategy-structure fit for matrix structures. Their results suggested that a region-product matrix was more likely with high product diversity, and a region-functional matrix was more likely for higher levels of foreign manufacturing. Internalization scholars have pointed to regional strategies and structures being driven by the need to reduce "spatial transaction costs" which limit transferability, deployment, and exploitation of firm specific advantages (FSAs) outside of an MNE's domestic market. These costs arise due to institutional, economic, cultural, geographic, and other differences between countries (Rugman \& Verbeke, 1992; Ghemawat, 2003). MNEs do combine FSAs with host country specific advantages (CSAs) such as markets, resources, and regulations to address these challenges and strengthen competitive advantage (Johansson \& Vahlne, 2009; Hennart, 2009). However, doing so at a regional rather than at a country level becomes optimal when intra-regional "spatial transaction costs” are much lower than those between regions. Further, the advantages of operating regionally are more pronounced for downstream value chain activities (e.g., sales, service, distribution and retail), which require commitments from key external stakeholders such as customers and partners (Rugman \& Verbeke, 2005). Hence, Rugman \& Verbeke (2008) extended the FSA/CSA framework with the concept of region-specific advantages requiring the presence of organizational structures supporting regional strategic decisions.

Regional Management Centre Roles. Researchers have extended the dominant view that regional management centres only serve as geographic extensions of corporate headquarters for purposes of regional coordination, control, governance, and information processing. For instance, Lasserre (1996), in a survey-based study on European MNEs in Asia, investigated the entrepreneurial and regional 
integration roles of RHQs. He identified a series of region-specific mandates that RHQs carry out at different stages during MNE internationalization processes. In a study of European RHQs, Hoenen, et al., (2014) discussed how RHQs, by being embedded across local, regional, and global markets, can help build MNE entrepreneurial capabilities. Asakawa \& Lehrer (2003) explained how certain RHQs transform local innovation into global strategic assets by identifying and nurturing local R\&D activity to develop knowledge, followed by dissemination of knowledge assets across the MNE network. Verbeke and Asmussen (2016) suggested that regional head office structures may be vital to identifying, absorbing, and disseminating new globally applicable knowledge from host-regions. They also emphasized the importance of RMCs in orchestrating regional value chains to exploit cross border resource and market differences, while achieving scale efficiencies.

Several studies describe how RMC roles may evolve over time. Based on a study of RHQs in Asia Pacific, Lasserre (1996) suggested that RHQs start off with an entrepreneurial orientation, serving as a base to seek opportunities, initiating new regional ventures, and helping subsidiaries to develop strategy. As the MNE becomes better established in the region and subsidiaries mature, RHQs take on coordinating and integrative functions, until they wind down almost completely or move into purely administrative roles. Ambos, Schlegelmilch, Ambos, and Brenner (2009) discussed how mergers and acquisitions (M\&As) outside of the home region may lead to regional management structures evolving over time. In a case study of an M\&A in the banking sector in Central and Eastern Europe (CEE), they found that post acquisition, the head office of the acquired bank was initially assigned a regional governance and standardisation role, which did not align well with its actual capabilities. Over time, driven by the need for legitimacy and influence, the unit strengthened its distinctive capabilities and transformed its role into a regional center of excellence in banking practices. Based on a longitudinal case study in a European MNE, Piekkari et al., (2010) suggested that matching regional management capabilities with information processing requirements is a complex process of evolution and adaptation. The MNE regional management system evolved at unit, regional, and corporate levels to address the need for internal, and external complexities at various levels, and inter-region differentiation. 
Regional Management Centre Configurations. Research has noted the presence of regional management structures distinct from dedicated RHQs. Enright (2005a, b) distinguished between regional offices and RHQs. Regional offices carry out coordination and supporting roles on behalf of MNE HQs but have no all-encompassing hierarchical authority over other subsidiaries in the same region. RHQs, in contrast, have more extensive mandates including full hierarchical control, which often involves the financial consolidation of all regional activities for the focal MNE (Enright, 2005a). Lasserre (1996) found that some companies mandate operating subsidiaries with regional management roles to avoid an extra layer of management bureaucracy and keep costs down. Along similar lines, Schütte (1997) discussed the concept of "virtual RHQs" wherein a dedicated RHQ does not exist, rather the responsibilities of a dedicated RHQ are distributed to existing subsidiaries through their directors/managers. Using a case study of Unilever across three Central European countries, Alfoldi et al., (2012) argued why operating subsidiaries with regional mandates (RMMs) should be treated as conceptually different from dedicated RHQs. They posited that while RMMs in smaller, peripheral markets offer cost, responsiveness, and information processing advantages (relative to more administratively focused RHQs with dedicated leadership and support staff), they may raise legitimacy concerns. Verbeke \& Asmussen (2016) noted that compared to dedicated RHQs, RMMs may prioritize operations in the country where they are located, at the expense of other countries in the region. For all these reasons, we expect materially different characteristics between RMMs and RHQs, as well as between MNEs which adopt different regional management configurations.

The remainder of this paper is organized into a sample and analysis section, followed by the presentation of results, discussion, and conclusion. Due to the exploratory nature of our study, we do not include a hypotheses development section, and provide explanations, theoretical propositions, and a preliminary conceptual model in the discussion section. 


\section{SAMPLE AND ANALYSIS}

\section{Data}

We utilized the Kaigai Shinshutsu Kigyo Soran (Japanese Overseas Investments) dataset (Toyo Keizai, 2010) as the primary data source. This dataset is updated annually and consists of panel data about foreign subsidiaries of Japanese MNEs. Our dataset includes almost the entire population of overseas affiliates of all publicly listed and non-listed Japanese companies during the time period from 1990 to 2009. We combined the Toyo Keizai dataset with the Nikkei Economic Electronic Database System published by Nihon Keizai Shimbun to add parent firm-level information. Sachwald (1995) concluded that the Toyo Keizai database is the most extensive and reliable longitudinal source for information on Japanese MNEs available today. Another advantage of using this dataset is that Japanese MNEs have a long internationalization history and that Japanese MNEs can be found in more than 150 different countries globally with extensive and consistent information available (Makino, Beamish, \& Zhao, 2004).

Sample selection and data integrity. The functional activities that affect an MNE's competitive advantage differ between small and large subsidiaries (e.g. Amit \& Schoemaker, 1993; Anand \& Delios, 1997; Hennart, 1991). We were interested in those RHQs and RMMs that have regional and operational mandates beyond just a representative office or sales office status and are therefore larger in size. We performed a series of robustness tests at different levels of RMC employee size to determine the validity of this criterion. We examined the sample distribution in terms of the number of employees at the foreign affiliate level, as suggested by Delios and Beamish (1999). The histogram of the natural logarithm ${ }^{\text {ii }}$ revealed two clustered distributions which converged at the count of nine employees. Second, we tested how RMC mandates changed at different cut-off points. The results confirmed that small foreign affiliates have strategic mandates less frequently than larger affiliates. Therefore, those foreign affiliates with fewer than nine employees were excluded from the sample. Affiliates with a Toyo Keizai industry sector code of "Regional Headquarters” were identified as RHQs; and non-RHQ affiliates with a venture creation objective of “Strengthening Regional Headquarters Function” were identified as RMMs. We excluded Regional Holding Companies from the sample since these are entities set-up for tax and jurisdictional 
purposes rather than for providing regional leadership. The final sample contains 855 unique RMCs (6,331 RMC-year cases) comprising 568 RMMs (4,567 RMM-year cases) and 311 RHQs (1,764 RHQyear cases). The unique RMM and RHQ numbers do not add up to 855 since 24 RMCs function as RMMs and RHQs at different points in time. These RMCs are deployed by 455 unique MNEs across 41 countries and 12,537 subsidiaries. Table 1 summarizes the RMC sample profile.

\section{INSERT TABLE 1 ABOUT HERE}

Missing data. We performed full information maximum likelihood (FIML) to address missing data for several variables and overcome potential sample bias due to incomplete data. Both FIML and multiple imputation methods yield robust standard errors and reduce errors in parameter estimates. However, unlike multiple imputation, FIML does not insert missing data. Instead, it corrects regression parameter estimates based on correlations across all variables in the model. FIML is deemed to be a superior alternative to multiple imputation since it is deterministic, takes into consideration every variable in the analysis model, is more efficient, and involves less uncertainty (Allison, 2012).

At an overall level, the sample has $27 \%$ missing data. The amount of missing data varies by variable, ranging from $0 \%$ to $70 \%$ across variables of interest. We performed FIML regressions for the following dependent variables (missing percentages shown in brackets): RMC performance (68\%), R\&D intensity (70\%), advertising intensity (70\%), and degree of internationalization (56\%). We did not perform FIML regressions for the following dependent variables (missing percentages shown in brackets): RMC revenue (30\%), RMC assets (30\%), RMC employees (30\%), MNE ROA (28\%) and MNE ROS (28\%), since variables with which they were strongly correlated were also simultaneously missing. We also did not perform FIML regressions for several other variables which had less than 5\% missing data. 


\section{Analysis}

To explore potential differences between RHQs and RMMs, one-way multivariate analysis of variance (MANOVA) tests were performed for continuous scale variables. Since the distributions of certain variables were skewed with long tails to the right, we used log transformations. ${ }^{\text {iii }}$ MANOVA is commonly used to examine differences in sample characteristics across categories (e.g. Egelhoff, 1982; Peng, Tan \& Tong, 2004). For example, Peng et al. (2004) used MANOVA to identify significant differences in characteristics across four types of strategic groups based on ownership types. Other studies have used analysis of variance as a tool for similar tests (Ketchen \& Shook, 1996; Osborne, Stubbart \& Ramaprasad, 2001; Peng \& Luo, 2000; Short, Ketchen, Palmer \& Hult, 2007).

For nominal variables, such as investment purpose, ownership modes, industries, and subsidiary locations, chi-square tests were performed using crosstabs (contingency tables). A modified Bonferroni procedure was employed in the follow-up tests for both MANOVA and chi-square statistics to apply a more stringent standard to the significance levels of p-values (Jaccard \& Wan, 1996). This corrected and controlled for Type 1 error inflation caused by multiple analyses of variance.

For certain dependent variables with missing values, we performed FIML OLS regressions for continuous variables and FIML logistic regressions for nominal variables. All statistical analyses in this study were performed as two-tailed tests (Leventhal \& Huynh, 1996). In addition to p-values, we report 95\% confidence intervals for all variables and the Cohen’s “d” as an effect size measure for all continuous variables (Cohen, 1988; 1992). Where the analysis involves logistic regression, we compute and report an equivalent Cohen’s d value by dividing the odds ratio by 1.81 (Chinn, 2000).

In the next section, we report the results. For readability purposes, we do not elaborate the specific differences in characteristics in detail here, as they are listed in Tables 1 to 11 and discussed in the subsequent section. However, for convenience, we summarize the specific characteristics and performance differences in Table 12. 


\section{RESULTS}

\section{Affiliate level sample profile}

RHQs and RMMs. Table 1 shows that from 1990 to 2009, Japanese MNE RMMs registered a five-fold increase, while RHQs tripled over the same time period. On average, there are over twice as many RMMs as RHQs (the annual average ratio is 2.6). The ratio has fluctuated between a low of 1.8 (in 1990) to a high of 3.4 (in 1995) and has increased steadily from 2.2 in 2004 to 3.1 in 2009. See Figure 1.

Regions. Table 2 indicates that in the triad region, Asia exhibits the largest growth in Japanese RMC numbers with about an eight-fold increase from 1990 to 2009. In Europe (EU) and North America (NA), RMCs have increased about three times over the same time period. In contrast to a pattern of growth followed by decline in EU and NA, Japanese MNE regular subsidiary numbers in Asia have grown steadily and more than doubled. However, the percentage of RMCs to subsidiaries has steadily increased over time in EU and NA and was around 7\% in both regions in 2009, significantly exceeding the RMC proportion in Asia (about 3\%). See Figures 2 and 3.

INSERT FIGURES 1-3 ABOUT HERE

Developed and developing economies. Table 3 depicts a proportional distribution over time of RHQs, RMMs, and regular subsidiaries between developed and developing countries. We note that in developed countries, RHQ, RMM, and regular subsidiary proportions have all reduced over time. However, the RHQ and RMM proportions in 2009 (62\% and 74\%) are considerably higher than for regular subsidiaries (41\%). In contrast, these proportions have all increased over time in developing countries. However, the RHQ and RMM proportions in 2009 (38\% and 24\%) are considerably lower than for regular subsidiaries (59\%). For nine out of the ten developed/developing countries, RHQ and RMM proportions are significantly higher/lower than the corresponding subsidiary proportions in 2009.

INSERT TABLES 1-3 ABOUT HERE 


\section{Foreign affiliate (RHQ, RMM) characteristics}

Investment purposes. Results suggest (Table 4) that RMMs have a significantly greater focus on market, resource, and efficiency seeking motivations (as a proportion of total) relative to RHQs. For instance, RMMs are twice as likely as RHQs to have set up production and distribution networks as an investment purpose. With regards to strategic purposes, RMMs have a substantially higher focus on innovation management and a higher proportion of information processing and knowledge seeking purposes. RHQs have a significantly greater focus on financial risk management. We also examined the nature of these differences per time period of affiliate establishment (pre-1980, 1980-89, 1990-99, and 2000-onwards). The differences in relative proportion of most investment purposes between RHQs and RMMs are consistent and significant over time except for strategic purposes. The significantly greater overall proportion of innovation management for RMMs arises from two periods during which R\&D purposes proportions were very low for RHQs (0\% pre-1980 and 4\% from the year 2000 onwards). The significantly greater overall RMM proportion of information and knowledge seeking purposes is largely due to RMM proportions (61\%) being more than twice as great as RHQ proportions (28\%) during the 1980-89 timeframe.

Dominant industries. Results in Table 5 show that RMMs and regular subsidiary proportions significantly differ across eight out of nine industry sectors (we do not examine RHQs in this context since they are not classified by industry sector). In particular, there is a substantially lower proportion of RMMs to conventional subsidiaries in manufacturing relative to wholesale, transportation, and retail. Over the period of 1990 to 2009, RMM proportions have increased relative to regular subsidiary proportions in the manufacturing and wholesale sectors.

Revenues, employees and start dates. Table 6 shows that RMMs and RHQs significantly differ across the dimensions of revenue and number of employees. These results hold for the overall sample and across each of the four time periods (1990-94; 1995-99, 2000-04, and 2005-09). RHQs have consistently higher revenues (about 1.5 times higher), but significantly lower employees (about half as much) compared to RMMs. Furthermore, the relative proportions of RMM and RHQ start dates differ 
significantly for each time period. In relative terms, the highest proportion of RMMs were established in the pre-1980 and 1980-99 periods, while the highest proportions of RHQ establishment occurred in the following two time periods (1990-99 and 2000-onwards).

Ownership and control. Table 7 indicates that on average, RHQs have significantly lower numbers of total parents, and Japanese parents than RMMs. However, RHQs have significantly higher levels of primary parent equity ownership and greater numbers and proportions of expatriate employees, relative to RMMs. RHQs are also more likely to be wholly-owned relative to RMMs. Two substantial trends over time are first that primary parent equity ownership for RMMs has increased from an average of $83 \%$ in $1990-94$ to $91 \%$ in 2005-2009; and second that for these time periods, the percentage of expatriates to total employees has decreased for both RHQs and RMMs from 32\% to 23\% and from 16\% to $10 \%$ respectively. See Figure 4 .

\section{INSERT FIGURE 4 ABOUT HERE}

\section{RHQ and RMM performance}

Logistic regression results (Table 8) show that relative to RMMs, RHQs have a significantly higher probability of breaking even and a significantly lower probability of unprofitable performance. RHQs and RMMs do not significantly differ in regard to probability of profitable performance.

\section{INSERT TABLES 4-8 ABOUT HERE}

\section{Parent level sample profile}

Table 1 also breaks down our sample of 455 Japanese MNEs with RMCs into three MNE types. The majority comprises 337 MNEs with RMMs only (64\%). 140 MNEs operate with RHQs only (27\%) and the 45 MNEs which have both RHQs and RMMs (dual model) constitute the minority at 9\%. The totals of the MNE types (522) are greater than 455 since 67 MNEs have over time adopted more than one 
RMC configuration. Figure 5 plots the number of MNEs corresponding to each RMC configuration from 1990 to 2009. The table and plot indicate that increase in RMCs since 2000 has been driven largely by growth in MNEs with RMMs only. Such MNEs have nearly quadrupled from 39 to 167 between 1990 and 2009, while MNEs with RHQs and dual model MNEs have only doubled and grown by 1.7 times respectively. Figure 6 depicts the time trend for the number of RMCs per MNE for each MNE type. The ratio of RMCs to MNEs has remained fairly steady at around 1.5 RMCs per MNE for MNEs with RMMs only as well as MNEs with RHQs. However, the corresponding ratio for dual model MNEs has nearly doubled from about 2 RMCs per MNE in 1990 to about 4 in 2009. In particular, the RMC to MNE ratio for the dual model shows accelerated growth for the timeframe 2005-2009.

\section{INSERT FIGURES 5-6 ABOUT HERE}

\section{RMC parent characteristics}

Table 9 shows that for the overall sample, MNEs with only RHQs have the highest levels of employees, revenues, total assets, and percentage of foreign sales, followed by MNEs with both RHQs and RMMs, followed by MNEs with RMMs only. However, R\&D intensity (percentage of R\&D expenditure to revenue) is significantly greater for MNEs with RHQs and RMMs, relative to MNEs with RHQs only. MNEs with RHQs only and MNEs with RHQs and RMMs also have significantly greater advertising intensities relative to MNEs with RMM's only. However, the difference between the first two MNE types are not significant.

We also compared employees, total assets, and revenues for the three MNE types over four time periods and found that during the initial period of our sample (1990-94), MNEs with both RHQs and RMMs had the highest levels of tangible assets. During 1995-99, firms with RHQs only had significantly more assets and revenues than firms with both RHQs and RMMs. Over the most recent time periods 2000-04 and 2004-09, firms with RHQs only had significantly higher tangible assets across all categories. 
We examined whether older MNEs were more likely to adopt a traditional RHQ only model, while newer MNEs adopt an RMM only model. We measured "international age” as the time period in years from an MNE's first foreign subsidiary establishment to the last year of observation. The average international age for MNEs with RHQs only is 44.2 years, while that of MNEs with RMMs only is 30.4 years. A t-test of means indicates the difference is significant, suggesting that all else being equal, older/newer MNEs are more likely to adopt an RHQ only/RMM only model.

\section{RMC parent performance}

Since MNE performance can vary considerably by industry sector, we examined two sub-samples for manufacturing parents and wholesale parents, which together constitute over 93\% of the MNEs with RMCs in our sample. Table 10 shows that within manufacturing, MNEs with only RHQs have significantly better performance in terms of return on assets (ROA) and return on sales (ROS) relative to the other MNE types. MNEs with both RHQs and RMMs perform significantly better than MNEs with only RMMs. These differences increase over time, i.e., they are substantially higher over the periods 2000-04 and 2005-09 relative to 1990-94 and 1995-99.

Within the wholesale sector, this pattern is reversed (see Table 11) i.e., MNEs with only RMMs have significantly better performance than MNEs with both RHQs and RMMs, which have performed better than those MNEs with only RHQs. These differences are also substantially higher for the later time periods of 2000-04 and 2005-09.

\section{Regional structure evolution}

At an affiliate level, twenty-four RMCs in our sample are classified as RHQs and RMMs at different points in time. Of these, thirteen were initially RMMs and later transformed to RHQs, while eleven were RHQs to begin with. At the parent level, we find sixty-seven MNEs with RMCs changed their regional management model over time. Twenty-two of them shifted between RMM only to RHQ only models (11 each). Twenty-three used an RHQ only model as well as the dual model (RMMs and RHQs), with the majority of these (17) initially establishing RHQ only configurations. Thirty-two MNEs adopted an RMM 
only as well as a dual model at different points in time, with most of them (25) shifting from an RMM only model to the dual model.

Overall, the empirical results demonstrate that (a) Japanese MNE deployment of RMCs varies considerably by region and country; (b) at the foreign affiliate level, RHQs and RMMs differ significantly in terms of characteristics and performance; (c) the three types of MNEs which use RMCs as part of their governance structure (those with both RHQs and RMMs, those with only RHQs, and those with only RMMs) differ significantly from each other in regard to characteristics and performance; and (d) there are some notable trends over time concerning RMC establishment, characteristics and performance at the affiliate and parent levels. Table 12 summarizes the findings.

\section{INSERT TABLES 9-12 ABOUT HERE}

\section{DISCUSSION}

This study investigates whether and how RMCs (RHQs and RMMs) differ from each other at the affiliate level, whether and how MNEs that use diverse RMC configurations differ from each other, and how these differences evolve over time. The results of our investigation show that several important differences exist at both the sub-unit and the parent firm level. Based on our findings, we inform the classic integration-responsiveness (I-R) framework (Bartlett \& Ghoshal, 1989), by specifying regional structural components, which complement the regional strategy dimension introduced by Verbeke \& Asmussen (2016). While Table 12 summarizes the findings, in this section, we explain some of our key findings in depth, develop corresponding propositions, and provide a preliminary conceptual model (Figure 8). We also provide brief explanations for several other findings. 


\section{Theoretical contributions}

The original I-R framework draws upon the strategy-structure-performance (SSP) sub-stream of contingency theory (Chandler, 1966; Lawrence \& Lorsch, 1967; Rumelt, 1974), which suggests that optimal outcomes are determined by the fit between a firm's external environment, its strategy, and its organizational approach. The I-R framework provides a two-dimensional depiction of an MNE's environment - pressures for achieving global integration on one hand (to realize cost efficiencies and maintain consistency through scale, standardization, and control); and pressures for achieving local responsiveness on the other (to tailor products to country differences such as customer preferences, regulations, and institutions). When integration and responsiveness pressures are high and low respectively, a standardized "global” approach to products, and processes with centralized decision making is recommended. When integration pressures are low and responsiveness pressures are high, a “multi-domestic” approach with autonomy delegated to country subsidiaries is recommended.

However, as Verbeke and Asmussen (2016) point out, it is less clear what MNEs should do when both pressures are high i.e., what is an optimal "transnational” approach, since for instance, “a product cannot be simultaneously standardized and locally adapted” (p.14). Hence the authors introduced into the framework a regional strategy dimension which maintains consistency within a region, while adapting to inter-regional differences. This approach provides regional economies of scale as well as regional responsiveness when regions are sufficiently large and internally homogeneous markets but differ substantially from each other, and may therefore represent a feasible response to a transnational environment. By incorporating the regional dimension into the I-R framework, Verbeke and Asmussen (2016) extend the possible strategic responses from three to six Blocks (1. global, 2. multi-domestic, 3. transnational, 4. global or regional, 5. regional and 6. multi-domestic or regional) as shown in Figure 7.

Our findings provide a structural complement to the above regional strategy extension of the I-R framework. RHQs have been proposed as a structural model for transnational strategy (e.g., Paik \& Sohn, 2004), while RMMs have been proposed as a cost-efficient model for “new, peripheral, or transitional markets” (Alfoldi et al., 2012). Such suggestions, which are based on case-studies may have very limited 
generalizability - for instance, we find evidence that in large, developed markets such as North America and Europe, most wholesale Japanese MNEs use RMMs. Our investigation of RHQs and RMMs' proportions and performance by industry sector enables a finer grained theoretical mapping of structure to regional strategy. We find a higher proportion of RMMs (to regular subsidiaries) in downstream value chain industries such as wholesale, retail, and transportation; and a lower proportion in manufacturing. Our analysis suggests that in the wholesale sector, MNEs with an RMM-only model perform best, followed by those with a dual model (RHQs and RMMs), followed by MNEs with RHQs only. For manufacturing, the pattern is reversed and MNEs with an RHQ-only model are the best performers. RHQs are often focused on identifying synergies and implementing scale efficiencies through centralized support functions and administration, with weak links to primary value chain activities in subsidiaries (Paik \& Sohn, 2004; Ghemawat, 2005; Alfoldi et al., 2012). Our finding that RHQs are established far more frequently for financial risk mitigation relative to RMMs (23\% to $8 \%$ ) underscores this point. This is particularly salient for Japanese MNEs, which have traditionally operated in a largely centralized manner (e.g., R\&D in subsidiaries coordinated with HQ through expatriate engineers), with most RHQs functioning as administrative units with little autonomy (Lehrer \& Asakawa, 1999; Edgington \& Hayter, 2012). Consequently, we find far fewer RHQs established for R\&D purposes relative to RMMs (11\% to $18 \%)$.

RMMs being large operating subsidiaries are likely to possess strong technical and operational capabilities, and more likely to be embedded in regional business, information, and relationship networks. Johanson \& Vahlne (2009) theorized that knowledge and business relationships derived from industryspecific experience, and being embedded in business networks of customers, suppliers, and partners may be critical to MNE success. In the regional context, such experience may be particularly important for several MNEs, since their customer-partner-supplier network may have a greater degree of intra-region (relative to inter-region) consistency. We do find a substantially higher proportion of RMMs motivated by the need to follow customers and partners into new markets relative to RHQs (14\% to 4\%). Hence, RMMs are likely to respond better to changing requirements of regional market situations than RHQs. 
From an information processing standpoint (Piekkari et al., 2010), the wholesale MNE business model, (and particularly Japanese MNE wholesale) relies on a high degree of flexible, low cost, and quick responses in cross-border information processing, which may be best served by a regional RMM governance model. Japanese MNE wholesalers have extremely diversified business lines (Larke \& Davies, 2007) with firms such as Itochu, Mitsui, Sumitomo, and Tomen trading in numerous global markets across a broad spectrum of products. Such companies rely on extensive albeit low cost, responsive, and tactical information processing networks to respond to and translate into business opportunities the regulatory, economic, social, and technological changes in international markets (Dziubla, 1982; UNCTAD, 2005). Hence for wholesale MNEs, RMMs (rather than RHQs) may be more effective for improving cost and speed of regional information processing because they provide more localized resources at a lower cost (Alfoldi et al., 2012), and are likely to be better connected to regional business and information networks. We find RMMs are established more frequently for information processing and knowledge seeking purposes relative to RHQs (56\% to 47\%); and pertinently, a greater proportion of wholesale RMMs are focused on information-sharing and knowledge-seeking (61\%) relative to manufacturing RMMs (41\%). From an internalization perspective, wholesale is a downstream value chain sector, with location-bound FSAs that may benefit from cross-border knowledge sharing, regional coordination, and resource recombinations across operating functions (Verbeke \& Kano, 2016).

Hence, as our performance findings reveal, wholesale MNEs may be best served by a regionally responsive RMM model. We posit this to be generally applicable for MNEs in Block 6, where pressures for regional responsiveness in the context of a regional strategy are relatively higher. In contrast, an upstream value chain sector (e.g., manufacturing), with a high degree of non-location bound FSAs, may benefit from a more globally integrated and efficient model, which as our performance findings suggest is best served by an RHQ model. We posit this to be generally applicable for MNEs in Block 4 where pressures for global integration in the context of a regional strategy are relatively higher. For MNEs with transnational strategies (Block 3), we argue that a dual model governance structure comprising RHQs to facilitate integration and efficiency and RMMs to enable better operational responsiveness is ideal. In 
Block 5, which corresponds to moderate levels of integration and responsiveness pressures, we contend that either an RHQ or an RMM based model may be appropriate. (See Figure 7).

Proposition 1: In the context of regional strategy, MNEs emphasizing global integration are likely to implement and benefit from an RHQ-only model; MNEs focused on regional responsiveness are likely to implement and benefit from an RMM-only model; transnational organizations are likely to implement a dual model; and either an RHQ-only or an RMM-only model is likely to serve well the needs of MNEs facing moderate levels of integration and responsiveness pressures.

Proposition 2: Downstream value chain sectors (e.g., wholesale, retail) benefit from RMM governance models which favour regional responsiveness; while upstream value chain sectors (e.g., manufacturing) benefit from RHQ governance models which favour global integration.

Proposition 3: MNEs for whom leveraging regional business and relationship networks is vital to success, are more likely to segregate regional administrative functions from co-ordination of primary value chain activities and rely on governance models which include RMMs (RMM only or RHQ+RMM).

Our findings may also explain some variation in regional governance structures from the above propositions. We find a higher proportion of RHQs relative to subsidiaries and RMMs within the EU and NA, and a lower proportion in Asia. Such relative focus on developed regions and locations may reflect institutional and resource-based characteristics which facilitate RMC investment. Ease of doing business, availability of capable personnel, stronger institutional environments (Yeung et al., 2001; Zhou, 2015), as well as expatriate preferences for locations with high living standards (Schotter \& Beamish, 2013) may be key drivers of RMC location choices. For instance, Zhou (2015) found that within an MNE, units in stronger institutional environments are more likely to regionally supervise subsidiaries located in countries with weak institutions. Further, these proportions may be driven by a path-dependent international expansion process (Penrose, 1959), which leverages and adapts existing resources and FSAs while seeking new opportunities (Verbeke \& Kano, 2012). Until 1995, the vast majority of Japanese FDI and RHQs were concentrated within the EU and NA. We note (Table 2 and Figure 2) the marked increase 
in Asia RMC numbers commencing in 1995 - which is consistent with the start of a long decline in Japan’s economy. Many Japanese MNEs came under pressure to reduce costs by moving production bases to developing nations, especially China (Makino et al., 2004). This operational shift necessitated greater coordination and control regarding Asian operations. However, despite shifting investment trends towards Asia, rather than establishing additional Asian RHQs, several MNEs with a long history of internationalization could use existing RHQs or a combination of existing RHQs and new RMMs to manage growth in emerging markets.

We also find that the oldest and largest MNEs with the most tangible assets, and the highest percentages of foreign sales tend to establish RHQs only, with smaller firms establishing RMMs only, and with intermediate firms being most likely to adopt a dual (RHQ+RMM) regional governance model. This is also consistent with our prior finding regarding older MNEs adopting an RHQ only model, since older MNEs are more likely to have higher levels of employees, revenues, and assets. Dedicated RHQs are high cost solutions, and require scale efficiencies to be viable, compared to assigning additional regional (RMM) responsibility to a regular subsidiary (Alfoldi et al., 2012). Hence larger MNEs are more likely to have an RHQ only or a dual regional governance model. Finally, a number of smaller MNEs may manage home region operations from corporate HQ (CHQ). For instance, several Japanese MNEs use their CHQ in Japan to manage expansion in Asia, rather than establish dedicated RHQs. Such MNEs are therefore more likely to designate large subsidiaries as RMMs.

For the above reasons, regional strategy-structure considerations notwithstanding, MNEs may leverage a combination of existing RHQs and CHQ with or without RMMs to manage expansion into new countries/regions or within their home region.

Proposition 4: MNEs with a long history of internationalization, and larger MNEs (assets, revenues, employees, percentage foreign sales, and footprint extending beyond their home region), are likely to implement an RHQ-only or a dual (RHQ+RMM) model.

Figure 8 depicts a preliminary conceptual framework based on the four propositions developed. 


\section{Explanations of other findings}

Affiliate-level characteristics. We find that RHQs generate relatively more revenue than RMMs (about 1.5 times as much), but have about half the number of employees. This indicates that most RHQs consolidate financials across subsidiaries in the region and underscores that in addition to their regional mandates, RMMs are large operating subsidiaries. RHQs and RMMs do not significantly differ in their proportions of profitable performance (about 63\% each). However, RHQs are about 1.6 times more likely to break-even (from the odds ratio), but about 1.5 times less likely to be unprofitable relative to RMMs. Hence, RHQs are on average less risky than RMMs, and the data suggest that diversification of risk based on RHQ financial consolidation mandates at the regional level is the main reason.

We find RHQs show greater average equity ownership levels than RMMs (96\% vs. 87\%) and are also more likely to be wholly owned (94\% vs. 76\%). While RMMs do share the control and standardization mandate with RHQs, they are also driven by the need to exploit local knowledge, and hence form equity ventures with local partners, to operate successfully in the domestic market. The RMM focal parent equity ownership increase over time (83\% in 1990-94 to 91\% in 2005-09) may also be driven by a need to compensate for the decline in expatriate percentage (about 100\% between 1990 to 2009), since expatriates represent an important coordination and control mechanism for MNEs. With RHQs, equity ownership has remained very high at about 96\% through 1990-2009.

The decline in absolute number of expatriates and expatriate percentage over time for both RHQs and RMMs (about 60\% between 1990 to 2009) is consistent with prior empirical research on Japanese subsidiaries. Beamish and Inkpen (1998) provide two explanations. First, Japanese MNEs had to hire locals because of a limited supply of expatriate managers, and second, Japanese MNEs are recognizing the benefits of empowering local management and competing in a truly global manner.

Parents with RMCs: numbers and growth. Our sample includes 455 MNEs which deploy 855 RMCs across 12,537 subsidiaries, resulting in an average of about two RMCs per MNE and 14 regular subsidiaries per RMC. MNEs which deploy both RMMs and RHQs (dual model) have greater numbers of RMCs per MNE (average of over 3) relative to MNEs which deploy either RMMs or RHQs (average of 
1.5 for both). The much greater ratio for MNEs with the dual model is partly driven by substantial fluctuation in MNE and corresponding RMC numbers during the period 2005-2009. In this timeframe, the dual model MNE numbers dropped by about 10\% while their RMM numbers rose by $70 \%$ and RHQ numbers declined by $15 \%$. This suggests several Japanese MNEs may have in response to the Global Financial Crisis (2007-2009), increased their adoption of lower cost RMM models, driven by the need to achieve both fiscal prudence and greater subsidiary control.

\section{CONCLUSION}

With this study, we respond to calls for more research on MNE HQ disaggregation and specifically on the RMC phenomenon (e.g. Alfoldi et al., 2012; Ambos \& Schlegelmilch, 2010; Baaij \& Slangen, 2013; Cantwell, 2009; Lunnan \& Zhao, 2014). To the best of our knowledge, this is the first large sample study to offer a detailed overview of specific characteristics and performance differences between RHQs and RMMs based on a longitudinal global dataset. Given the exploratory nature of our study, we theorize expost, proposing a structural complement to Verbeke \& Asmussen’s (2016) regional strategy extension of the I-R framework, and developing four propositions on the relationship between MNE characteristics, regional strategy, regional structure, and performance.

We find that RMMs and RHQs exhibit substantially different characteristics with regard to venture creation logics, levels of employees, revenues, industry sector of operation, ownership and control modes, and performance. We also find that several characteristics (e.g., strategic establishment purposes, focal MNE equity ownership) evolve over time. At the MNE level, we find three modes of regional governance - MNEs with RMMs (majority), MNEs with RHQs, and MNEs with both RMMs and RHQs (minority). These three MNE types differ in terms of MNE performance based on industry sector, with the RMM only model performing best in wholesale and the RHQ model performing best in manufacturing. 
Given these results, scholars should not assume a convergence of characteristics over time or homogeneous RMC configurations across regions and industry sectors. While some overarching commonalities may exist, and persist, several unique characteristics may influence the relationship between strategy, structure, and performance (Mudambi, 2011; Stopford \& Wells, 1972; Wolf \& Egelhoff, 2002). For example, an RMM regional model may increase the likelihood of joint ventures and alliances across the region, due to the RMM's industry expertise and embeddedness in business networks. On the other hand, an RHQ model may increase the likelihood of wholly-owned and globally integrated subsidiaries. Hence, we suggest that international business researchers include the type of regional governance model in their research design, while examining strategy-structure-performance relationships.

On a related note, we also underscore the need to account for variations in MNE foreign affiliates. RHQs, RMMs, and regular subsidiaries need to be separated in studies that investigate MNE strategy and/or performance. If these three affiliate types are not differentiated, particularly for empirical analyses, potential issues could arise. For example, studies investigating expatriate employee levels, location choices, location-specific performance, and asset or size based performance metrics could come to misleading conclusions depending on the type and prevalence of RMCs in the data sample.

In addition to formally testing our propositions, our findings and analysis provide several avenues for future research. The first entails understanding and explaining the relative prevalence and evolution of diverse regional governance models. We find that RMMs outnumber RHQs by more than 2:1 on average, and the majority of Japanese MNEs (64\%) adopt an RMM only model. This contrasts with prior research (e.g., Laserre, 1996; Alfoldi et al., 2012) which expects RHQs to be the dominant form of regional management organization. We also note during the period 1999-2009, RMM numbers grew by about 30\%, while RHQs remained relatively stagnant. This trend is mirrored at the MNE level, with the RMM only model gaining over time, while the dual and RHQ only models show signs of decline and stagnation respectively. While prior research has briefly pointed to such phenomena, it has not made the distinction between RHQs and RMMs. Lehrer \& Asakawa (1999) discussed the phenomenon of smaller and flexible specialized regional management units in Japanese MNEs increasing over time. Lasserre (1996) posited 
that after regional subsidiaries gain maturity, the role of RHQs becomes administrative and marginal, until they finally “disappear”. What explains the relative prevalence and growth of RMM based governance models, which we find from our large, longitudinal study of Japanese MNEs? Is this simply a more efficient model in terms of cost, co-ordination, and information and knowledge processing? Is this generalizable across contexts (e.g., Japanese, U.S., European MNEs)? We call for focused primary data source based investigations to understand and explain this phenomenon better.

On a related note, similarities and differences between European, US, and Japanese models of regional management is a second research topic that would benefit from more large-scale empirical investigations. Most research on the RMC phenomenon (like this one) are ethnocentric in terms of the MNEs studied and the few that span across different countries of MNE origin (e.g., Lehrer \& Asakawa (1999)) are smaller scale qualitative studies. For instance, Lehrer and Asakawa (1999) found that while these US and Japanese MNEs started their regionalization efforts from different ends of the integrationresponsiveness spectrum i.e., multi-domestic (US) and global (Japanese), MNEs from both countries have gravitated to intermediate positions in the recent past. It would be particularly interesting to examine whether the use of RMMs is as prevalent within US MNEs as it is with Japanese MNEs, and whether balancing the need for integration with responsiveness through RMMs has led to convergence between the two models.

A third avenue springs from identifying the demarcation of roles and functions between RHQs and RMMs. We find that RMMs have a significantly and substantially greater proportion of strategic motivations, relative to RHQs, such as R\&D, product planning, and information and knowledge dissemination. However, prior case-study based literature (Alfoldi et al., 2012) suggests that strategic decision-making is one of the RHQ functions, which RMMs are unlikely to engage in. We note there may be a distinction between investment rationales, which we examine, versus actual roles and functions performed. Future research should probe deeper into understanding if there is a disaggregation of coordination and control functions (Benito et al., 2011) and entrepreneurial and knowledge-based processes (Hoenen et al., 2014) between RHQs and RMMs respectively. 
A fourth and related area of promise entails investigating how innovation specific roles and functions differ between RHQs and RMMs. A key challenge for MNEs is tapping into and managing innovation that is both globally dispersed and locally embedded (Lunnan \& Zhao, 2014; Meyer, Mudambi, \& Narula, 2011). RMCs may be well positioned to do so, given their embeddedness in global, local, and regional contexts (Hoenen et al., 2014). Our study finds that less than 20\% of sample RMCs are established with an investment purpose of managing innovation. Despite not necessarily having an R\&D mandate, RMCs may mediate innovation relays between HQ and regional subsidiaries (Asakawa \& Lehrer, 2003). However, understanding and analysing the specific and distinct innovation focused interventions that RMMs and RHQs perform is an area which requires further research. For instance, RMMs being large operating subsidiaries with technical know-how may have a more hands-on role in fostering bottom-up innovation and implementing top-down innovation within the region. In contrast, RHQs may have a more administrative innovation management role involving collection, dissemination, and standardisation of R\&D practices and procedures.

Finally, this research provides a large (near-population) sample baseline of RMC characteristics and performance. We contribute to theory by providing a structural complement to regional strategy in the context of the I-R framework. However, our investigation is purposefully exploratory and our primary goal is to inform subsequent theory building and empirical research into MNE regional management strategy and structure, rather than to develop or test theory. We believe that a lot of commonly held views and assumptions regarding RMC characteristics (e.g., relative prevalence of different RMC configurations, distinctions with regards to roles and purposes of RHQs and RMMs) have become widely accepted through practitioner experience and detailed, albeit small sample size studies by academics without being backed by large scale empirical studies. Consequently, research in the area has moved on to a process view, bypassing the base-case view, which has never been firmly established. Primarily, our work seeks to address this gap. 


\section{REFERENCES}

Alfoldi, E., Clegg, L. \& McGaughey, S. (2012). Coordination at the edge of the empire: The delegation of headquarters functions through regional management mandates. Journal of International Management, 18(3): 276-292.

Allison, P. D. (2012, April). Handling missing data by maximum likelihood. Keynote presentation at the SAS Global Forum, Orlando, FL. Available at http://www.statisticalhorizons. com/wpcontent/uploads/MissingDataByML.pdf.

Ambos, B., \& Schlegelmilch, B. B. (2010). The New Role of Regional Management. New York: Palgrave Macmillan.

Ambos, T. C., Schlegelmilch, B. B., Ambos, B., \& Brenner, B. (2009). Evolution of organisational structure and capabilities in internationalising banks: The CEE operations of UniCredit's Vienna office. Long Range Planning, 42(5): 633-653.

Amit, R., \& Schoemaker, P. (1993). Strategic assets and organizational rent. Strategic Management Journal, 14(1): 33-46.

Anand, J., \& Delios, A. (1997). Location specificity and the transferability of downstream assets to foreign subsidiaries. Journal of International Business Studies, 28(3): 579-603.

Anderson, E., \& Gatignon, H. (1986). Modes of foreign entry: A transaction cost analysis and propositions. Journal of International Business Studies, 17(3): 1-26.

Asakawa, K., \& Lehrer, M. (2003). Managing local knowledge assets globally: The role of regional innovation relays. Journal of World Business, 38(1): 31-42.

Baaij, M., \& Slangen, A. (2013). The role of headquarters-subsidiary geographic distance in strategic decisions by spatially disaggregated headquarters. Journal of International Business Studies, 44(9): 941-952.

Bartlett, C. A., \& Ghoshal, S. (1989). Managing across Borders: The Transnational Solution. Boston, MA: Harvard Business School Press.

Beamish, P. W., \& Inkpen, A. C. (1998). Japanese firms and the decline of the Japanese expatriate. Journal of World Business, 33(1): 35-50.

Benito, G. R., Lunnan, R., \& Tomassen, S. (2011). Distant encounters of the third kind: Multinational companies locating divisional headquarters abroad. Journal of Management Studies, 48(2): 373-394.

Chandler, A.D., Jr. (1966). Strategy and Structure. New York, NY: Doubleday, Anchor Books Edition.

Chinn, S. (2000). A simple method for converting an odds ratio to effect size for use in metaanalysis. Statistics in Medicine, 19(22), 3127-3131.

Cohen, J. (1988). Statistical power analysis for the behavioral sciences (2nd ed.). Hillsdale, NJ: Erlbaum

Cohen, J. (1992). A power primer. Psychological Bulletin, 122(1): 155-159.

Collinson, S., \& Rugman, A. (2008). The regional nature of Japanese multinational business. Journal of International Business Studies, 39(2): 215-230.

Delios, A., \& Beamish, P. (1999). Ownership strategy of Japanese firms: Transactional, institutional, and experience influences. Strategic Management Journal, 20(10): 915-933.

Dziubla, R. W. (1982). International Trading Companies: Building on the Japanese Model. Northwestern Journal of International Law \& Business, 4(2):422.

Edgington, D. W., \& Hayter, R. (2013). “Glocalization” and Regional Headquarters: Japanese Electronics Firms in the ASEAN Region. Annals of the Association of American Geographers, 103(3): 647-668.

Egelhoff, W. (1982). Strategy and structure in multinational corporations: An information-processing approach. Administrative Science Quarterly, 27(3): 435-458.

Egelhoff, W. (1988). Strategy and structure in multinational corporations: A revision of the Stopford and Wells model. Strategic Management Journal, 9(1): 1-14.

Enright, M. (2005a). The roles of regional management centers. Management International Review, 45(1): 83102.

Enright, M. (2005b). Regional management centers in the Asia-Pacific. Management International Review, 45(1): 59-82.

Ghemawat, P. (2003). Semiglobalization and international business strategy. Journal of International Business Studies, 34(2): 138-152.

Ghemawat, P. (2005). Regional strategies for global leadership. Harvard Business Review, 83(12): 98-108. 
Heenan, D. (1979). Regional headquarters decision: A comparative analysis. Academy of Management Journal, 22(2): 410-415.

Hennart, J. F. (2009). Down with MNE-centric theories! Market entry and expansion as the bundling of MNE and local assets. Journal of International Business Studies, 40(9): 1432-1454.

Hennart, J. F. (1991). The transaction costs theory of joint ventures: An empirical study of Japanese subsidiaires in the United States. Management Science, 37(4): 483-497.

Hoenen, A. K., Nell, P. C., \& Ambos, B. (2014). MNE entrepreneurial capabilities at intermediate levels: The roles of external embeddedness and heterogeneous environments. Long Range Planning, 47(1): 76-86.

Hoenen, A. K., \& Kostova, T. (2014). Utilizing the broader agency perspective for studying headquarterssubsidiary relations in multinational companies. Journal of International Business Studies, 46(1): 104113.

Jaccard, J., \& Wan, C. (1996). LISREL Approaches to Interaction Effects in Multiple Regressions. Thousand Oaks, CA: Sage Publications.

Johanson, J., \& Vahlne, J. (2009). The Uppsala internationalization process model revisited: From liability of foreignness to liability of outsidership. Journal of International Business Studies, 40(9): 1411-1431.

Kähäri, P. (2015). Why do regional headquarters live and die?. AIB Insights, 15(3): 9.

Ketchen, D., \& Shook, C. (1996). The application of cluster analysis in strategic management research: An analysis and critique. Strategic Management Journal, 17(6): 441-458.

Larke, R., \& Davies, K. (2007). Recent changes in the Japanese wholesale system and the importance of the Sogo Shosha. International Review of Retail, Distribution and Consumer Research, 17(4), 377-390.

Lasserre, P. (1996). Regional headquarters: The spearhead for Asia Pacific markets. Long Range Planning, 29(1): 30-37.

Lawrence, P. R., \& Lorsch, J. W. (1967). Differentiation and integration in complex organizations. Administrative Science Quarterly, 12(1), 1-47.

Lehrer, M., \& Asakawa, K. (1999). Unbundling European operations: Regional management and corporate flexibility in American and Japanese MNCs. Journal of World Business, 34(3): 267-286.

Leventhal, L., \& Huynh, C. L. (1996). Directional decisions for two-tailed tests: Power, error rates, and sample size. Psychological Methods, 1(3): 278-292.

Li, G., Yu, C., \& Seetoo, D. (2010). Toward a theory of regional organization. Management International Review, 50(1): 5-33.

Lunnan, R., \& Zhao, Y. (2014). Regional headquarters in China: Role in MNE knowledge transfer. Asia Pacific Journal of Management, 31(2): 397-422.

Mahnke, V., Ambos, B., Nell, P., \& Hobdari, B. (2012). How do regional headquarters influence corporate decisions in networked MNCs? Journal of International Management, 18(3): 293-301.

Makino, S., Beamish, P. W., \& Zhao, N. (2004). The characteristics and performance of Japanese FDI in less developed and developed countries. Journal of World Business, 39(4): 377-392.

Mudambi, R. (2011). Hierarchy, coordination, and innovation in the multinational enterprise. Global Strategy Journal, 1(3-4): 317-323.

Meyer, K. E., Mudambi, R., \& Narula, R. (2011). Multinational enterprises and local contexts: The opportunities and challenges of multiple embeddedness. Journal of Management Studies, 48(2): 235252.

Nell, P. C., Ambos, B., \& Schlegelmilch, B. B. (2011). The MNC as an externally embedded organization: An investigation of embeddedness overlap in local subsidiary networks. Journal of World Business, 46(4): 497-505.

Osborne, J., Stubbart, C., \& Ramaprasad, A. (2001). Strategic groups and competitive enactment: A study of dynamic relationships between mental models and performance. Strategic Management Journal, 22(5): 435-454.

Paik, Y., \& Sohn, J. H. (2004). Striking a balance between global integration and local responsiveness: The case of Toshiba corporation in redefining regional headquarters' role. Organizational Analysis, 12(4): 347-359.

Parks, F. (1969). Survival of European headquarters. Harvard Business Review, 47(2): 79-84.

Peng, M., \& Luo, Y. (2000). Managerial ties and firm performance in a transition economy: The nature of a micro-macro link. Academy of Management Journal, 43(3): 486-501. 
Peng, M., Tan, J., \& Tong, T. (2004). Ownership types and strategic groups in an emerging economy. Journal of Management Studies, 41(7): 1105-1129.

Penrose, E. T. (1959). The Theory of the Growth of the Firm. New York: John Wiley.

Piekkari, R., Nell, P. \& Ghauri, P. (2010). Regional management as a system: A longitudinal case study. Management International Review, 50(4): 513-532.

Prahalad, C. K., \& Doz, Y. L. (1987). The Multinational Mission: Balancing Local Demands and Global Vision. New York: Free Press.

Rugman, A. M., \& Verbeke, A. (1992). A note on the transnational solution and the transaction cost theory of multinational strategic management. Journal of International Business Studies, 23(4): 761-771.

Rugman, A., \& Verbeke, A. (2004). A perspective on regional and global strategies of multinational enterprises. Journal of International Business Studies, 35(1): 3-18.

Rugman, A.M., \& Verbeke, A. (2005). Towards a Theory of Regional Multinationals: A Transaction Cost Economics Approach. Management International Review, 45(1): 5-17.

Rugman, A., \& Verbeke, A. (2008). A regional solution to the strategy and structure of multinationals. European Management Journal, 26(5): 305-313.

Rumelt, R. P. (1974). Strategy, Structure, and Economic Performance. Cambridge, MA: Harvard University Press.

Sachwald, F. (1995). Japanese Firms in Europe. Luxembourg: Harwood Academic Publishers.

Schlie, E., \& Yip, G. (2000). Regional follows global: Strategy mixes in the world automotive industry. European Management Journal, 18(4): 343-354.

Schotter, A., \& Beamish, P. W. (2013). The hassle factor: An explanation for managerial location shunning. Journal of International Business Studies, 44(5): 521-544.

Short, J., Ketchen, D., Palmer, T., \& Hult, G. (2007). Firm, strategic group, and industry influences on performance. Strategic Management Journal, 28(2): 147-167.

Stopford, J., \& Wells, L. (1972). Managing the Multinational Enterprise: Organization of the Firm and Ownership of the Subsidiaries. New York: Basic Books.

Sullivan, D. (1992). Organization in American MNCs: The perspective of the European regional headquarters. Management International Review, 32(3): 237-250.

Toyo Keizai. (2010). Kaigai Shinshutsu Kigyo Souran. Tokyo: Toyo Keizai.

UNCTAD Trade and Development Report (2006). New Features of Global Interdependence. New York and Geneva: UNCTAD.

Verbeke, A., \& Asmussen, C. G. (2016). Global, Local, or Regional? The Locus of MNE Strategies. Journal of Management Studies (forthcoming).

Verbeke, A., \& Kano, L. (2012). An internalization theory rationale for MNE regional strategy. Multinational Business Review, 20(2): 135-152.

Verbeke, A., \& Kano, L. (2016). An internalization theory perspective on the global and regional strategies of multinational enterprises. Journal of World Business, 51(1): 83-92.

Wolf, J., \& Egelhoff, W. (2002). A reexamination and extension of international strategy-structure theory. Strategic Management Journal, 23(2): 181-189.

Yeung, H., Poon, J., \& Perry, M. (2001). Towards a regional strategy: The role of regional headquarters of foreign firms in Singapore. Urban Studies, 38(1): 157-183.

Zhou, Y. M. (2015). Supervising Across Borders: The Case of Multinational Hierarchies. Organization Science, 26(1): 277-292. 
Table 1 Affiliate-level and Parent-level sample profiles

\begin{tabular}{|c|c|c|c|c|c|c|c|c|c|c|c|c|c|c|c|}
\hline \multirow[t]{3}{*}{ Year } & \multicolumn{4}{|c|}{ Affiliate-level } & \multicolumn{10}{|c|}{ Parent-level } & \multirow[t]{3}{*}{$\begin{array}{c}\text { Total } \\
\text { MNEs } \\
\end{array}$} \\
\hline & & & & & \multicolumn{3}{|c|}{ MNEs with RMMs } & \multicolumn{3}{|c|}{ MNEs with RHQs } & \multicolumn{4}{|c|}{ MNEs with RHQs and RMMs } & \\
\hline & RMM & RHQ & RMC & $\begin{array}{c}\text { RMM/ } \\
\text { RHQ }\end{array}$ & MNE & RMM & $\begin{array}{l}\text { RMM/ } \\
\text { MNE }\end{array}$ & MNEs & RHQ & $\begin{array}{l}\text { RHQ/ } \\
\text { MNE }\end{array}$ & MNE & RMM & RHQ & $\begin{array}{l}\text { RMC/ } \\
\text { MNE }\end{array}$ & \\
\hline 1990 & 66 & 36 & 102 & 1.8 & 39 & 57 & 1.5 & 28 & 31 & 1.1 & 15 & 19 & 15 & 2.3 & 82 \\
\hline 1991 & 100 & 41 & 141 & 2.4 & 59 & 94 & 1.6 & 31 & 35 & 1.1 & 15 & 16 & 16 & 2.1 & 105 \\
\hline 1992 & 119 & 46 & 165 & 2.6 & 66 & 112 & 1.7 & 30 & 40 & 1.3 & 17 & 17 & 17 & 2.0 & 113 \\
\hline 1993 & 148 & 49 & 197 & 3.0 & 84 & 140 & 1.7 & 32 & 39 & 1.2 & 17 & 18 & 20 & 2.2 & 133 \\
\hline 1994 & 159 & 54 & 213 & 2.9 & 96 & 151 & 1.6 & 33 & 44 & 1.3 & 17 & 18 & 20 & 2.2 & 146 \\
\hline 1995 & 176 & 52 & 228 & 3.4 & 119 & 170 & 1.4 & 32 & 46 & 1.4 & 15 & 16 & 16 & 2.1 & 166 \\
\hline 1996 & 206 & 75 & 281 & 2.7 & 129 & 198 & 1.5 & 46 & 65 & 1.4 & 18 & 18 & 20 & 2.1 & 193 \\
\hline 1997 & 224 & 82 & 306 & 2.7 & 139 & 214 & 1.5 & 53 & 73 & 1.4 & 17 & 20 & 19 & 2.3 & 209 \\
\hline 1998 & 227 & 93 & 320 & 2.4 & 141 & 212 & 1.5 & 58 & 83 & 1.4 & 18 & 25 & 20 & 2.5 & 217 \\
\hline 1999 & 248 & 101 & 349 & 2.5 & 152 & 232 & 1.5 & 60 & 85 & 1.4 & 20 & 26 & 26 & 2.6 & 232 \\
\hline 2000 & 255 & 100 & 355 & 2.6 & 154 & 239 & 1.6 & 63 & 89 & 1.4 & 19 & 25 & 21 & 2.4 & 236 \\
\hline 2001 & 253 & 112 & 365 & 2.3 & 147 & 234 & 1.6 & 65 & 97 & 1.5 & 20 & 28 & 25 & 2.7 & 232 \\
\hline 2002 & 267 & 106 & 373 & 2.5 & 154 & 248 & 1.6 & 58 & 87 & 1.5 & 21 & 29 & 29 & 2.8 & 233 \\
\hline 2003 & 280 & 118 & 398 & 2.4 & 162 & 254 & 1.6 & 56 & 89 & 1.6 & 26 & 36 & 39 & 2.9 & 244 \\
\hline 2004 & 284 & 128 & 412 & 2.2 & 167 & 259 & 1.6 & 52 & 91 & 1.8 & 26 & 35 & 47 & 3.2 & 245 \\
\hline 2005 & 299 & 122 & 421 & 2.5 & 179 & 269 & 1.5 & 55 & 86 & 1.6 & 29 & 40 & 46 & 3.0 & 263 \\
\hline 2006 & 298 & 110 & 408 & 2.7 & 181 & 268 & 1.5 & 53 & 79 & 1.5 & 26 & 40 & 41 & 3.1 & 260 \\
\hline 2007 & 314 & 121 & 435 & 2.6 & 169 & 263 & 1.6 & 53 & 79 & 1.5 & 30 & 61 & 52 & 3.8 & 252 \\
\hline 2008 & 316 & 112 & 428 & 2.8 & 167 & 269 & 1.6 & 55 & 78 & 1.4 & 27 & 57 & 44 & 3.7 & 249 \\
\hline 2009 & 328 & 106 & 434 & 3.1 & 167 & 270 & 1.6 & 53 & 77 & 1.5 & 26 & 68 & 39 & 4.1 & 246 \\
\hline \multirow[t]{2}{*}{ Total $^{\text {abc }}$} & (568) & (311) & (855) & & (337) & & & (140) & & & (45) & & & & (455) \\
\hline & 4567 & 1764 & 6331 & & 2671 & & & 966 & & & 217 & & & & 3854 \\
\hline
\end{tabular}

a. Total unique RMMs, RHQs, RMCs, and unique MNEs for each configuration (in brackets). Total affiliate-year cases, and MNE-year cases (in italics)

b. The sum of unique RMMs (568) + RHQs (311) totals 879, which is greater than the number of unique RMCs (855) by 24 . The difference is due to 24 sample RMCs which were initially RMMs, but were classified as RHQs later, or vice-versa.

c. The sum of unique MNEs across the three categories (337+140+45) totals 522, which is greater than the number of unique MNEs with RMCs (455) by 67. The difference is due to 67 sample MNEs which adopt more than one of the three RMC configurations over time. 
Table 2 Triad Regions

\begin{tabular}{|c|c|c|c|c|c|c|c|c|c|c|c|c|c|c|c|}
\hline \multirow[t]{2}{*}{ Year } & \multicolumn{5}{|c|}{ ASIA } & \multicolumn{5}{|c|}{$\mathrm{EU}^{\mathrm{a}}$} & \multicolumn{5}{|c|}{$\mathrm{NA}^{\mathrm{b}}$} \\
\hline & RMM & RHQ & RMC & Sub $^{c}$ & RMC/Sub & RMM & RHQ & $\mathrm{RMC}$ & Sub. & RMC/Sub & RMM & RHQ & RMC & Sub. & RMC/Sub \\
\hline 1990 & 23 & 6 & 29 & 3616 & $0.80 \%$ & 25 & 15 & 40 & 1368 & $2.92 \%$ & 17 & 14 & 31 & 1969 & $1.57 \%$ \\
\hline 1991 & 30 & 6 & 36 & 3956 & $0.91 \%$ & 39 & 15 & 54 & 1529 & $3.53 \%$ & 30 & 19 & 49 & 2118 & $2.31 \%$ \\
\hline 1992 & 40 & 9 & 49 & 4226 & $1.16 \%$ & 45 & 15 & 60 & 1629 & $3.68 \%$ & 33 & 21 & 54 & 2194 & $2.46 \%$ \\
\hline 1993 & 56 & 9 & 65 & 4558 & $1.43 \%$ & 50 & 15 & 65 & 1739 & $3.74 \%$ & 41 & 24 & 65 & 2220 & $2.93 \%$ \\
\hline 1994 & 59 & 13 & 72 & 5039 & $1.43 \%$ & 54 & 17 & 71 & 1782 & $3.98 \%$ & 45 & 23 & 68 & 2288 & $2.97 \%$ \\
\hline 1995 & 68 & 12 & 80 & 5618 & $1.42 \%$ & 54 & 17 & 71 & 1764 & $4.02 \%$ & 52 & 21 & 73 & 2229 & $3.28 \%$ \\
\hline 1996 & 91 & 25 & 116 & 6395 & $1.81 \%$ & 59 & 21 & 80 & 1835 & $4.36 \%$ & 53 & 28 & 81 & 2286 & $3.54 \%$ \\
\hline 1997 & 104 & 30 & 134 & 6872 & $1.95 \%$ & 60 & 20 & 80 & 1835 & $4.36 \%$ & 58 & 31 & 89 & 2276 & $3.91 \%$ \\
\hline 1998 & 104 & 35 & 139 & 7125 & $1.95 \%$ & 63 & 23 & 86 & 1823 & $4.72 \%$ & 58 & 34 & 92 & 2232 & $4.12 \%$ \\
\hline 1999 & 113 & 38 & 151 & 7272 & $2.08 \%$ & 71 & 26 & 97 & 1794 & $5.41 \%$ & 61 & 36 & 97 & 2168 & $4.47 \%$ \\
\hline 2000 & 122 & 41 & 163 & 7282 & $2.24 \%$ & 65 & 28 & 93 & 1729 & $5.38 \%$ & 66 & 29 & 95 & 2098 & $4.53 \%$ \\
\hline 2001 & 123 & 50 & 173 & 7452 & $2.32 \%$ & 63 & 29 & 92 & 1806 & $5.09 \%$ & 63 & 31 & 94 & 2092 & $4.49 \%$ \\
\hline 2002 & 133 & 46 & 179 & 7333 & $2.44 \%$ & 70 & 27 & 97 & 1759 & $5.51 \%$ & 59 & 32 & 91 & 1971 & $4.62 \%$ \\
\hline 2003 & 144 & 52 & 196 & 7520 & $2.61 \%$ & 70 & 28 & 98 & 1679 & $5.84 \%$ & 62 & 37 & 99 & 1876 & $5.28 \%$ \\
\hline 2004 & 145 & 63 & 208 & 7676 & $2.71 \%$ & 71 & 26 & 97 & 1642 & $5.91 \%$ & 65 & 37 & 102 & 1771 & $5.76 \%$ \\
\hline 2005 & 152 & 57 & 209 & 7747 & $2.70 \%$ & 75 & 25 & 100 & 1578 & $6.34 \%$ & 67 & 38 & 105 & 1734 & $6.06 \%$ \\
\hline 2006 & 154 & 53 & 207 & 7846 & $2.64 \%$ & 73 & 22 & 95 & 1516 & $6.27 \%$ & 65 & 32 & 97 & 1667 & $5.82 \%$ \\
\hline 2007 & 164 & 58 & 222 & 7921 & $2.80 \%$ & 70 & 26 & 96 & 1449 & $6.63 \%$ & 74 & 34 & 108 & 1635 & $6.61 \%$ \\
\hline 2008 & 163 & 54 & 217 & 7869 & $2.76 \%$ & 68 & 21 & 89 & 1438 & $6.19 \%$ & 78 & 34 & 112 & 1631 & $6.87 \%$ \\
\hline 2009 & 167 & 56 & 223 & 7925 & $2.81 \%$ & 80 & 20 & 100 & 1410 & $7.09 \%$ & 73 & 27 & 100 & 1537 & $6.51 \%$ \\
\hline
\end{tabular}

a. EU: Europe
b. NA: North America
c. Sub: Regular Subsidiary 
Table 3 Developed and developing economies ${ }^{\text {abcd }}$

\begin{tabular}{|c|c|c|c|c|c|c|}
\hline Countries & $\begin{array}{l}\text { Subsidiary } \\
\text { (\% of total) }\end{array}$ & $\begin{array}{l}\text { RMM } \\
\text { (\% of total) }\end{array}$ & $\begin{array}{l}\text { RHQ } \\
\text { (\% of total) }\end{array}$ & p-value & $\begin{array}{c}95 \% \text { CI } \\
\text { RMM- Sub. }\end{array}$ & $\begin{array}{r}95 \% \text { CI } \\
\text { RHQ-Sub. }\end{array}$ \\
\hline \multicolumn{7}{|l|}{ Developed } \\
\hline United States of America & $16.9 \%$ & $23.9 \%$ & $32.9 \%$ & $* * *$ & $(5.9 \%, 8.1 \%)$ & $(14.2 \%, 17.8 \%)$ \\
\hline Singapore & $4.8 \%$ & $13.1 \%$ & $16.2 \%$ & $* * *$ & $(7.7 \%, 8.9 \%)$ & $(10.4 \%, 12.4 \%)$ \\
\hline United Kingdom & $3.5 \%$ & $9.8 \%$ & $9.5 \%$ & $* * *$ & $(5.8 \%, 6.9 \%)$ & (5.1\%, 6.9\%) \\
\hline Hong Kong ${ }^{\mathrm{c}}$ & $4.5 \%$ & $11.3 \%$ & $4.4 \%$ & $* * *$ & $(6.2 \%, 7.4 \%)$ & Not significant \\
\hline Germany & $3.0 \%$ & $7.1 \%$ & $4.8 \%$ & $* *$ & $(3.6 \%, 4.6 \%)$ & $(0.1 \%, 2.6 \%)$ \\
\hline \multicolumn{7}{|l|}{ Developing } \\
\hline China & $17.0 \%$ & $6.6 \%$ & $13.2 \%$ & $* * *$ & $(9.3 \%, 11.5 \%)$ & $(2.0 \%, 5.6 \%)$ \\
\hline Thailand & $8.7 \%$ & $6.3 \%$ & $1.4 \%$ & $* * *$ & $(1.5 \%, 3.2 \%)$ & $(6.0 \%, 8.6 \%)$ \\
\hline Malaysia & $4.9 \%$ & $1.3 \%$ & $2.9 \%$ & $* *$ & $(3.0 \%, 4.2 \%)$ & $(1.0 \%, 3.6 \%)$ \\
\hline Indonesia & $4.3 \%$ & $1.5 \%$ & $0.4 \%$ & $* * *$ & $(2.2 \%, 3.4 \%)$ & $(3.0 \%, 4.9 \%)$ \\
\hline Brazil & $1.7 \%$ & $0.7 \%$ & $0.7 \%$ & $* *$ & $(0.6 \%, 1.4 \%)$ & $(0.4 \%, 1.6 \%)$ \\
\hline Developed countries (1990) & $69.9 \%$ & $89.4 \%$ & $97.3 \%$ & $* * *$ & $(18.2 \%, 20.8 \%)$ & $(25.3,29.5 \%)$ \\
\hline Developed countries ${ }^{\mathrm{C}}$ (2009) & $41.5 \%$ & $73.7 \%$ & $62.3 \%$ & $* * *$ & $(30.8 \%, 33.7 \%)$ & $(18.5 \%, 23.1 \%)$ \\
\hline Developing countries (1990) & $30.1 \%$ & $10.6 \%$ & $2.7 \%$ & $* * *$ & $(18.2 \%, 20.8 \%)$ & $(25.3 \%, 29.5 \%)$ \\
\hline Developing countries ${ }^{\mathrm{C}}$ (2009) & $58.5 \%$ & $24.3 \%$ & $37.7 \%$ & $* * *$ & $(30.8 \%, 33.7 \%)$ & $(18.5 \%, 23.1 \%)$ \\
\hline
\end{tabular}

$\dagger \mathrm{p}<0.1 \quad * \mathrm{p}<0.05 \quad * * \mathrm{p}<0.01 \quad * * * \mathrm{p}<0.001$

a. $\quad$ The top 5 developing and developed countries in terms of RMCs are shown in the table. All country numbers are for 2009.

b. The p-values represent significant differences between each of RHQ and RMM \% relative to subsidiary \%.

c. For Hong Kong, the difference between RHQ and subsidiary proportion is not significant.

d. $95 \%$ CI (confidence intervals) listed for difference between proportions. 
Table 4 Foreign investment purposes ${ }^{\text {ab }}$

\begin{tabular}{|c|c|c|c|c|}
\hline Investment purposes & RMM & RHQ & p-value & 95\% CI \\
\hline \multicolumn{5}{|l|}{ Market seeking } \\
\hline Access to local market & $80.9 \%$ & $57.1 \%$ & $* * *$ & $(20.6 \%, 27.1 \%)$ \\
\hline Follow customers and partners & $13.8 \%$ & $4.3 \%$ & $* * *$ & $(6.9 \%, 12.1 \%)$ \\
\hline New business development & $10.7 \%$ & $3.7 \%$ & $* * *$ & $(4.6 \%, 9.3 \%)$ \\
\hline Incentive from local government & $4.7 \%$ & $4.4 \%$ & & Not significant \\
\hline \multicolumn{5}{|l|}{ Resource seeking } \\
\hline Access to natural resources & $5.5 \%$ & $3.1 \%$ & $* *$ & $(0.7 \%, 4.2 \%)$ \\
\hline Offshoring & $10.9 \%$ & $0.7 \%$ & $* * *$ & $(7.8 \%, 12.4 \%)$ \\
\hline Export to a third country & $25.5 \%$ & $6.0 \%$ & $* * *$ & $(16.2 \%, 22.8 \%)$ \\
\hline \multicolumn{5}{|l|}{ Efficiency seeking } \\
\hline Establishment of production network & $24.5 \%$ & $12.2 \%$ & $* * *$ & $(8.4 \%, 14.9 \%)$ \\
\hline Establishment of distribution network & $46.6 \%$ & $23.1 \%$ & $* * *$ & $(19.6 \%, 27.4 \%)$ \\
\hline Access to labour force & $17.7 \%$ & $6.2 \%$ & $* * *$ & $(8.6 \%, 14.4 \%)$ \\
\hline \multicolumn{5}{|l|}{ Measures against trade friction } \\
\hline Strategic asset seeking & & & & $(4.2 \%, 10.2 \%)$ \\
\hline Product planning and R\&D & $18.1 \%$ & $10.9 \%$ & $* * *$ & $(4.9 \%, 12.8 \%)$ \\
\hline Information collection and knowledge-seeking & $56.0 \%$ & $47.1 \%$ & $* * *$ & \\
\hline \multicolumn{5}{|l|}{ Capital seeking (Financial risk management) } \\
\hline Finance and currency hedging & $8.5 \%$ & $22.7 \%$ & $* * *$ & $(11.8 \%, 16.6 \%)$ \\
\hline Measures against trade friction & $3.3 \%$ & $3.6 \%$ & & Not significant \\
\hline Not specified & $3.7 \%$ & $11.9 \%$ & $* * *$ & (6.5\%, 9.9\%) \\
\hline
\end{tabular}

$\dagger \mathrm{p}<0.1 \quad * \mathrm{p}<0.05 \quad * * \mathrm{p}<0.01 \quad * * * \mathrm{p}<0.001$

a. The original questionnaire allowed for multiple choices, so percentages in each purpose column will not add up to $100 \%$.

b. $\quad 95 \% \mathrm{CI}$ (confidence intervals) listed for difference between proportions.

Table 5 Dominant industries ${ }^{\mathrm{ab}}$

\begin{tabular}{lcccc}
\hline Industries & $\begin{array}{l}\text { Regular } \\
\text { Subsidiary }\end{array}$ & RMM & p-value & $\mathbf{9 5 \% ~ C I ~}$ \\
\hline Wholesale & $24.5 \%$ & $42.8 \%$ & $* * *$ & $(17.0 \%, 19.6 \%)$ \\
Manufacturing & $53.0 \%$ & $27.6 \%$ & $* * *$ & $(24.0 \%, 26.9 \%)$ \\
Transportation & $4.2 \%$ & $8.9 \%$ & $* * *$ & $(4.1 \%, 5.2 \%)$ \\
Services & $7.1 \%$ & $8.9 \%$ & $* * *$ & $(1.5 \%, 2.6 \%)$ \\
Retail & $2.7 \%$ & $4.3 \%$ & $* * *$ & $(1.1 \%, 2.1 \%)$ \\
Finance insurance and real estate & $4.6 \%$ & $5.0 \%$ & & Not significant \\
Construction & $2.6 \%$ & $3.5 \%$ & $* * *$ & $(0.4 \%, 1.4 \%)$ \\
Mining & $0.3 \%$ & $0.1 \%$ & $*$ & $(0.04 \%, 0.4 \%)$ \\
Agriculture, forestry and fishing & $0.6 \%$ & $0.0 \%$ & $* * *$ & $(0.4 \%, 0.8 \%)$ \\
& & & &
\end{tabular}

$\dagger \mathrm{p}<0.1 \quad * \mathrm{p}<0.05 \quad * * \mathrm{p}<0.01 \quad * * * \mathrm{p}<0.001$

a. RHQs are excluded since the dataset does not categorize RHQs by industry sector.

b. $\quad 95 \% \mathrm{CI}$ (confidence intervals) listed for difference between proportions. 
Table 6 Affiliate level characteristics ${ }^{a}$

\begin{tabular}{lccccc}
\hline & RMM & RHQ & p-value & 95\% CI & Cohen's d \\
\hline Revenue (thousand USD) & 181,115 & 272,178 & $*$ & $(18954,163170)$ & 0.11 \\
Number of employees & 327 & 148 & $*$ & $(25.5,330.6)$ & 0.10 \\
Start date & & & & & \\
$\quad$ Pre-1980 & $24.4 \%$ & $12.7 \%$ & $* * *$ & $(5.6 \%, 17.8 \%)$ & \\
$1980-1989$ & $33.1 \%$ & $20.9 \%$ & $* * *$ & $(6.7 \%, 17.5 \%)$ \\
$1990-1999$ & $35.0 \%$ & $47.4 \%$ & $* * *$ & $(7.8 \%, 16.17 \%)$ \\
Post 2000 & $7.4 \%$ & $19.0 \%$ & $* * *$ & $(6.4 \%, 16.8 \%)$ \\
\hline † & $* 0.1$ & $* * \mathrm{p}<0.01$ & $* * * \mathrm{p}<0.001$ &
\end{tabular}

a. $\quad 95 \%$ CI (confidence intervals) listed for difference between means for revenue and number of employees and for difference between proportions for start date.

Table 7 Ownership and control ${ }^{\mathrm{ab}}$

\begin{tabular}{lccccc}
\hline & RMM & RHQ & p-value & 95\% CIs & Cohen's d \\
\hline Ownership and Control & & & & & \\
\hline Total number of parents & 1.4 & 1.1 & $* * *$ & $(0.26,0.35)$ & 0.40 \\
$\quad$ Number of Japanese & 1.2 & 1.1 & $* * *$ & $(0.14,0.21)$ & 0.30 \\
$\quad$ parents & $86.7 \%$ & $96.3 \%$ & $* * *$ & $(8.3 \%, 10.7 \%)$ & 0.52 \\
$\quad$ Focal parent ownership & 7.7 & 12.3 & $* * *$ & $(3.8,5.5)$ & 0.37 \\
Expatriate number & $13.0 \%$ & $26.0 \%$ & $* * *$ & $(12.0 \%, 14.1 \%)$ & 0.78 \\
Expatriate percentage & & & & & 0.48 \\
Ownership Modes & $76.3 \%$ & $94.3 \%$ & $* * *$ & $(15.8 \%, 20.3 \%)$ & 0.34 \\
WOS & $7.7 \%$ & $2.9 \%$ & $* * *$ & $(3.4 \%, 6.2 \%)$ & 0.20 \\
Majority & $3.8 \%$ & $1.2 \%$ & $* * *$ & $(1.6 \%, 3.6 \%)$ & 0.19 \\
Even & $12.2 \%$ & $1.6 \%$ & $* * *$ & $(9.0 \%, 12.3 \%)$ & \\
Minority & & & & & \\
\end{tabular}

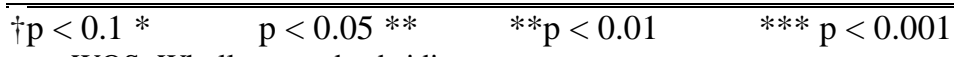

a. WOS: Wholly owned subsidiary

b. $\quad 95 \%$ CI (confidence intervals) listed for difference between proportions for all variables expressed in percentages and for difference between means for all other variables.

Table 8 Affiliate-level performance ${ }^{\mathrm{ab}}$

\begin{tabular}{|c|c|c|c|c|c|c|}
\hline & RMM & RHQ & p-value & Odds Ratio & $95 \% \mathrm{CI}$ & Cohen's d \\
\hline Gain & $63.5 \%$ & $63.2 \%$ & Not significant & 1.49 & $(1.03,2.1)$ & 0.82 \\
\hline Breakeven & $21.1 \%$ & $24.6 \%$ & $*$ & 1.60 & $(1.06,2.4)$ & 0.88 \\
\hline Loss & $15.4 \%$ & $12.2 \%$ & $*$ & $\begin{array}{l}\text { Reference } \\
\text { Category }\end{array}$ & & \\
\hline$\dagger p<0.1$ & ${ }^{*} \mathrm{p}<0.05$ & *** $\mathrm{p}<$ & $* * * \mathrm{p}<$ & 001 & & \\
\hline
\end{tabular}


Table 9 Parent level characteristics ${ }^{\text {abcd }}$

\begin{tabular}{|c|c|c|c|c|c|c|c|c|c|c|}
\hline & $\begin{array}{l}\text { MNEs with } \\
\text { RMMs (A) }\end{array}$ & $\begin{array}{l}\text { MNEs with } \\
\text { RHQs (B) }\end{array}$ & $\begin{array}{l}\text { MNEs with RHQs } \\
\text { \& RMMs (C) }\end{array}$ & $\begin{array}{c}p- \\
\text { value }\end{array}$ & $\begin{array}{l}95 \% \mathrm{CI} \\
(\mathrm{A}, \mathrm{B})\end{array}$ & $\begin{array}{c}\text { Cohen's d } \\
(\mathrm{A}, \mathrm{B})\end{array}$ & $\begin{array}{l}95 \% C I \\
(A, C)\end{array}$ & $\begin{array}{c}\text { Cohen's d } \\
(\mathrm{A}, \mathrm{C})\end{array}$ & $\begin{array}{l}95 \% \mathrm{CI} \\
(\mathrm{B}, \mathrm{C})\end{array}$ & $\begin{array}{c}\text { Cohen's d } \\
(\mathrm{B}, \mathrm{C})\end{array}$ \\
\hline Revenue ('000 USD) & 791,019 & $4,850,007$ & $3,395,365$ & $* * *$ & $(3977,4141)$ & 0.93 & $(2518,2961)$ & 0.84 & $(1375,1535)$ & 0.29 \\
\hline Number of employees & 9,811 & 54,459 & 63,650 & $* * *$ & $(43.4,45.9)$ & 0.86 & $(52.5,55.1)$ & 0.95 & $(7.9,10.3)$ & 0.12 \\
\hline Assets ('000 USD) & 599,592 & $3,629,978$ & $2,780,512$ & $* * *$ & $(2966,3095)$ & 0.87 & $(2113,2249)$ & 1.06 & $(787,912)$ & 0.21 \\
\hline R\&D intensity ${ }^{\mathrm{a}}$ & $1.9 \%$ & $2.8 \%$ & $3.5 \%$ & $* * *$ & $(1.3 \%, 3.8 \%)$ & 0.14 & $(2.2 \%, 5.6 \%)$ & 0.27 & $(0.8 \%, 2.7 \%)$ & 0.25 \\
\hline Advertising intensity ${ }^{\mathrm{ab}}$ & $1.4 \%$ & $1.6 \%$ & $1.5 \%$ & $* * *$ & $(0.1 \%, 0.3 \%)$ & 0.19 & $(0.08 \%, 0.24 \%)$ & 0.23 & Not significant & \\
\hline Deg. of internationalization ${ }^{\mathrm{a}}$ & $38.8 \%$ & $43.9 \%$ & $40.6 \%$ & $* * *$ & $(5.3 \%, 6.3 \%)$ & 0.54 & $(2.0 \%, 3.2 \%)$ & 0.36 & $(3.0 \%, 4.0 \%)$ & 0.55 \\
\hline
\end{tabular}

$\dagger \mathrm{p}<0.1 \quad * \mathrm{p}<0.05 \quad * * \mathrm{p}<0.01 \quad * * * \mathrm{p}<0.001$

a. FIML regression for R\&D intensity, advertising intensity and degree of internationalization

b. For advertising intensity, the difference between MNEs with RHQs and MNEs with RHQs and RMMs is not significant

c. $95 \% \mathrm{CI}$ (confidence intervals) listed for difference between means for all variables.

d. $95 \%$ CI listed in millions of USD for revenue and assets and in thousands for employees.

Table 10 Parent-level performance: Manufacturing ${ }^{\mathrm{a}}$

\begin{tabular}{|c|c|c|c|c|c|c|c|c|c|c|}
\hline $\begin{array}{l}\text { Performance } \\
\text { Metric }\end{array}$ & $\begin{array}{l}\text { MNEs with } \\
\text { RMMs (A) }\end{array}$ & $\begin{array}{l}\text { MNEs with } \\
\text { RHQs (B) }\end{array}$ & $\begin{array}{l}\text { MNEs with } \\
\text { RHQs \& RMMs } \\
\text { (C) }\end{array}$ & p-value & $\begin{array}{l}95 \% \mathrm{CI} \\
(\mathrm{A}, \mathrm{B})\end{array}$ & $\begin{array}{l}\text { Cohen's } \\
\text { d }(\mathbf{A}, \mathbf{B})\end{array}$ & $\begin{array}{l}95 \% \mathrm{CI} \\
(\mathrm{A}, \mathrm{C})\end{array}$ & $\begin{array}{l}\text { Cohen's } \\
\text { d }(A, C)\end{array}$ & $\begin{array}{l}95 \% \mathrm{CI} \\
(\mathrm{B}, \mathrm{C})\end{array}$ & $\begin{array}{l}\text { Cohen's } \\
\text { d }(B, C)\end{array}$ \\
\hline ROA & $2.8 \%$ & $3.5 \%$ & $3.1 \%$ & $* * *$ & $(0.5 \%, 0.8 \%)$ & 0.14 & $(0.2 \%, 0.4 \%)$ & 0.07 & $(0.3 \%, 0.5 \%)$ & 0.08 \\
\hline ROS & $3.0 \%$ & $4.0 \%$ & $3.4 \%$ & $* * *$ & $(0.8 \%, 1.1 \%)$ & 0.14 & $(0.2 \%, 0.5 \%)$ & 0.05 & $(0.4 \%, 0.7 \%)$ & 0.11 \\
\hline
\end{tabular}

a. $\quad 95 \% \mathrm{CI}$ (confidence intervals) listed for difference between means for all variables.

Table 11 Parent-level performance: Wholesale

\begin{tabular}{|c|c|c|c|c|c|c|c|c|c|c|}
\hline $\begin{array}{l}\text { Performance } \\
\text { Metric }\end{array}$ & $\begin{array}{l}\text { MNEs with } \\
\text { RMMs (A) }\end{array}$ & $\begin{array}{l}\text { MNEs with } \\
\text { RHQs (B) }\end{array}$ & $\begin{array}{l}\text { MNEs with RHQs } \\
\text { \& RMMs (C) }\end{array}$ & $\begin{array}{c}p- \\
\text { value }\end{array}$ & $\begin{array}{l}\text { 95\% CI } \\
(\mathrm{A}, \mathrm{B})\end{array}$ & $\begin{array}{l}\text { Cohen's } \\
\text { d }(A, B)\end{array}$ & $\begin{array}{l}95 \% \mathrm{CI} \\
(\mathrm{A}, \mathrm{C})\end{array}$ & $\begin{array}{l}\text { Cohen's } \\
\text { d }(A, C)\end{array}$ & $\begin{array}{l}95 \% \mathrm{CI} \\
(\mathrm{B}, \mathrm{C})\end{array}$ & $\begin{array}{l}\text { Cohen's } \\
\text { d }(B, C)\end{array}$ \\
\hline ROA & $2.6 \%$ & $1.3 \%$ & $1.4 \%$ & $*$ & $(1.2 \%, 1.4 \%)$ & 0.56 & $(1.03 \%, 1.28 \%)$ & 0.48 & $(0.05 \%, 0.25 \%)$ & 0.08 \\
\hline ROS & $1.3 \%$ & $0.6 \%$ & $1.0 \%$ & $* * *$ & $(0.6 \%, 0.7 \%)$ & 0.40 & $(0.26 \%, 0.42 \%)$ & 0.19 & $(0.25 \%, 0.38 \%)$ & 0.27 \\
\hline
\end{tabular}

a. $\quad 95 \%$ CI (confidence intervals) listed for difference between means for all variables. 
Table 12 Summary of differences between RMMs and RHQs

\begin{tabular}{|c|c|c|}
\hline & RMM & RHQ \\
\hline Investment purposes & $\begin{array}{l}\text { Access to local market } \\
\text { Information processing } \\
\text { Distribution network } \\
\text { Production network } \\
\text { R\&D }\end{array}$ & $\begin{array}{l}\text { Access to local market } \\
\text { Information processing } \\
\text { Financial risk management }\end{array}$ \\
\hline Dominant industries & $\begin{array}{l}\text { Wholesale } \\
\text { Transportation } \\
\text { Retail }\end{array}$ & Not applicable $^{\mathrm{a}}$ \\
\hline $\begin{array}{l}\text { Dominant regions and } \\
\text { countries }\end{array}$ & $\begin{array}{l}\text { Europe and North America } \\
\text { United States, Singapore, Hong Kong } \\
\text { United Kingdom, Germany }\end{array}$ & $\begin{array}{l}\text { Europe and North America } \\
\text { United States, Singapore, China, } \\
\text { United Kingdom, Germany }\end{array}$ \\
\hline $\begin{array}{l}\text { Foreign affiliate } \\
\text { characteristics }\end{array}$ & $\begin{array}{l}\text { Lower Revenue } \\
\text { More Employees } \\
\text { Most RMMs established 1980-1989 }\end{array}$ & $\begin{array}{l}\text { Higher Revenue } \\
\text { Fewer Employees } \\
\text { Most RHQs established 1990-1999 }\end{array}$ \\
\hline Ownership and control & $\begin{array}{l}\text { Lower focal parent equity ownership } \\
\text { Larger number of parents } \\
\text { Lower expatriate percentage } \\
\text { Lower percentage WOS }\end{array}$ & $\begin{array}{l}\text { Higher focal parent equity ownership } \\
\text { Smaller number of parents } \\
\text { Higher expatriate percentage } \\
\text { Higher percentage WOS }\end{array}$ \\
\hline $\begin{array}{l}\text { Foreign affiliate } \\
\text { performance }\end{array}$ & $\begin{array}{l}\text { High percentage of profitable units } \\
\text { Lower percentage of break-even units } \\
\text { Higher percentage of unprofitable units } \\
\text { MNEs with RMMs }\end{array}$ & $\begin{array}{l}\text { High percentage of profitable units } \\
\text { Higher percentage of break-even units } \\
\text { Lower percentage of unprofitable units } \\
\text { MNEs with RHQs }\end{array}$ \\
\hline Parent firm resources & $\begin{array}{l}\text { Fewer employees } \\
\text { Lower revenue } \\
\text { Lower total assets }\end{array}$ & $\begin{array}{l}\text { More employees } \\
\text { Higher revenue } \\
\text { Higher total assets }\end{array}$ \\
\hline Parent firm capabilities & $\begin{array}{l}\text { Lower R\&D intensity } \\
\text { Lower Advertising intensity }\end{array}$ & $\begin{array}{l}\text { Higher R\&D intensity } \\
\text { Higher Advertising intensity }\end{array}$ \\
\hline $\begin{array}{l}\text { Parent degree of } \\
\text { internationalization }\end{array}$ & Lower foreign sales & Higher foreign sales \\
\hline $\begin{array}{l}\text { Manufacturing MNE } \\
\text { performance }\end{array}$ & Lower ROA, Lower ROS & Higher ROA, Higher ROS \\
\hline $\begin{array}{l}\text { Wholesale MNE } \\
\text { performance }\end{array}$ & Higher ROA, Higher ROS & Lower ROA, Lower ROS \\
\hline
\end{tabular}

a. The dataset does not categorize RHQs by industry sector. 
Figure 1 RMMs, RHQs, and RMM to RHQ ratio: 1990-2009

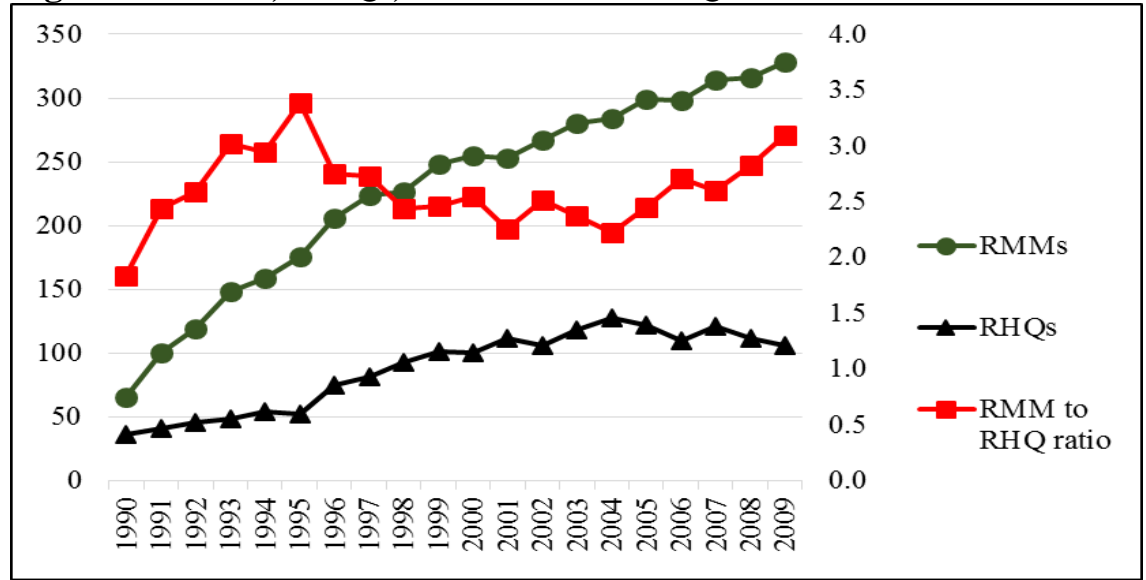

Note: Primary Axis (on left) corresponds to numbers of RMMs and RHQs. Secondary Axis (on right) corresponds to RMM to RHQ ratio.

Figure 2 RMC numbers in Triad regions: 1990-2009

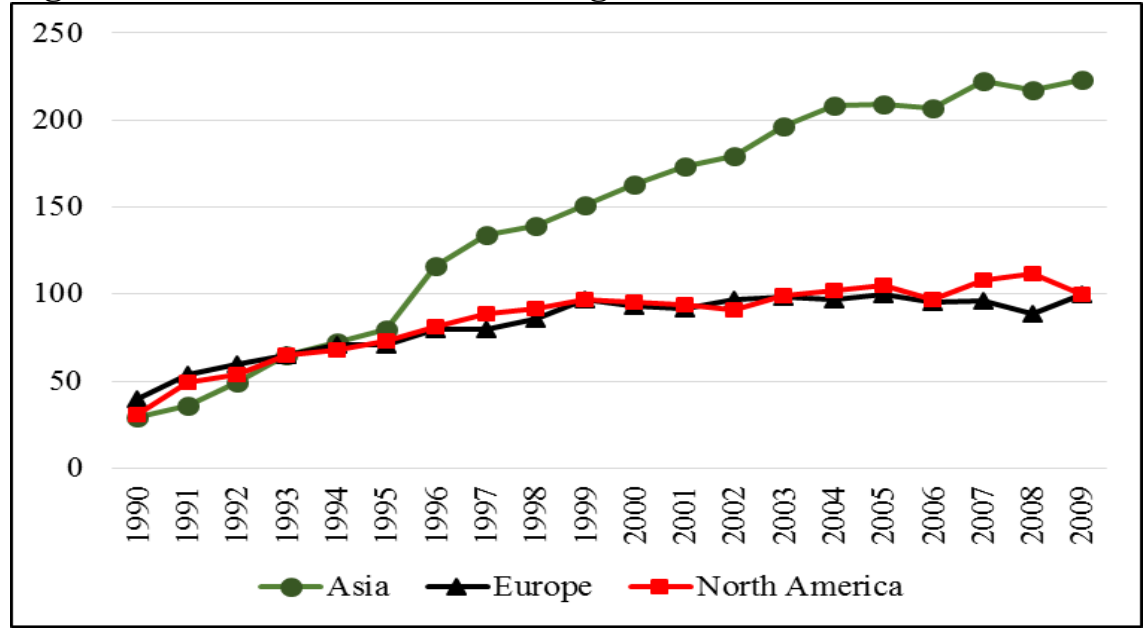

Figure 3 RMCs as a percentage of regular subsidiaries in Triad regions: 1990-2009

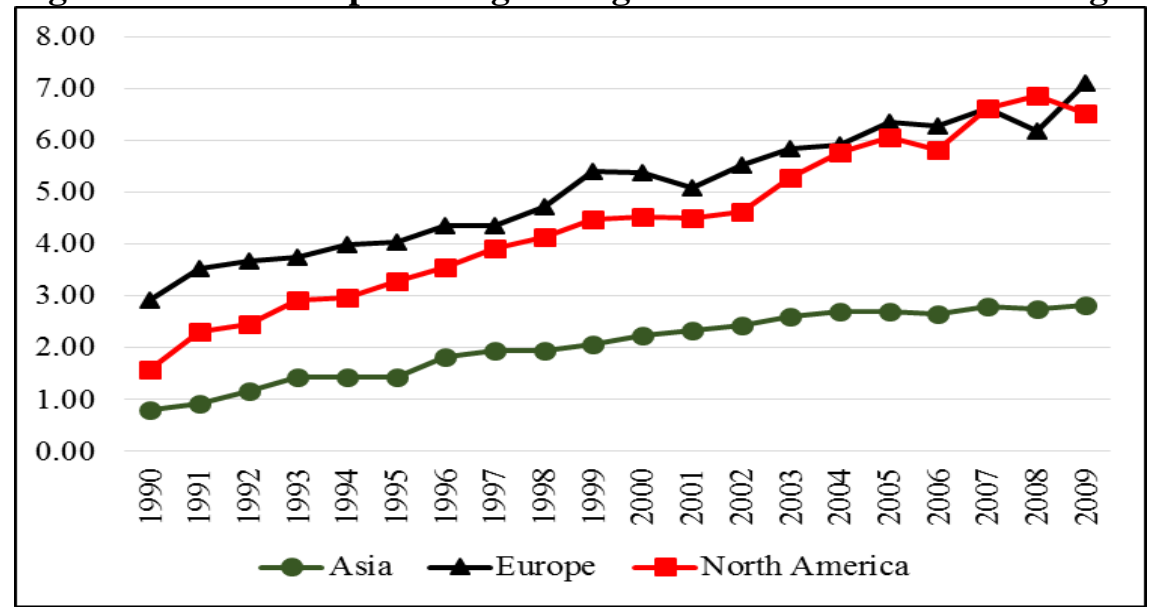


Figure 4 RMC Primary Parent Equity\% and Expatriate\%: 1990-2009

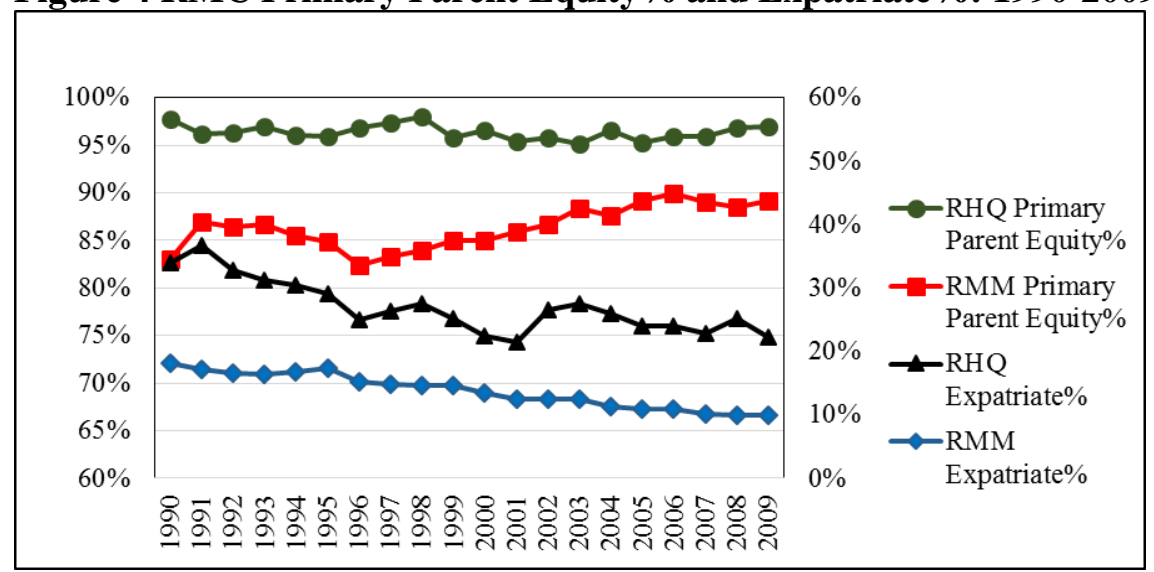

Note: Primary Axis (on left) corresponds to Primary Parent Equity\%. Secondary Axis (on right) corresponds to Expatriate\% (expatriates as a percentage of total RMC employees).

Figure 5 MNEs with different RMC configurations: 1990-2009

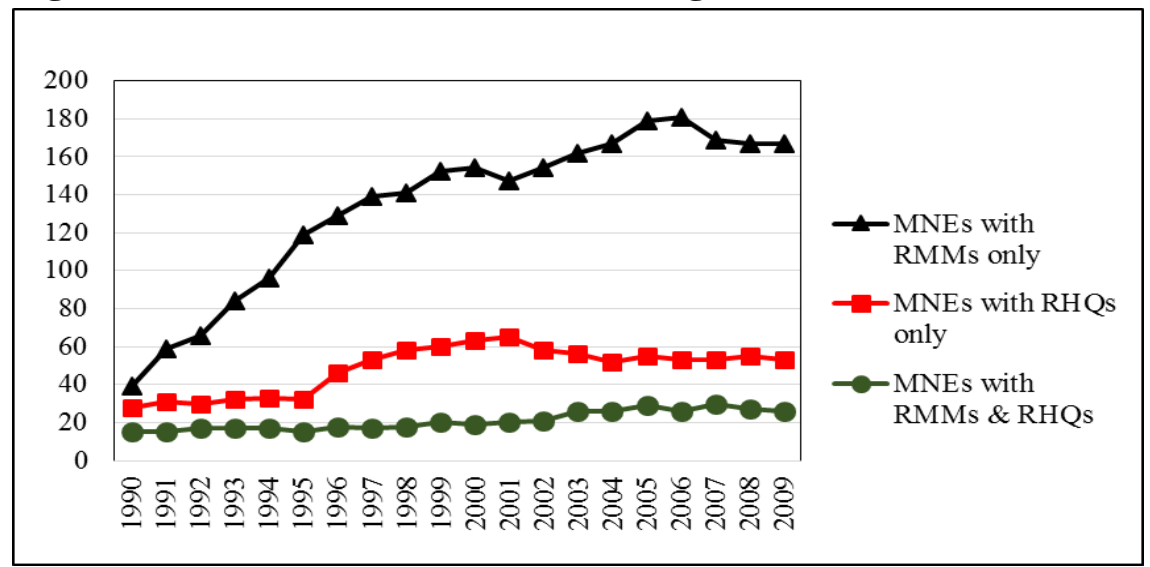

Figure 6 RMC to MNE ratio for MNEs with different RMC configurations: 1990-2009

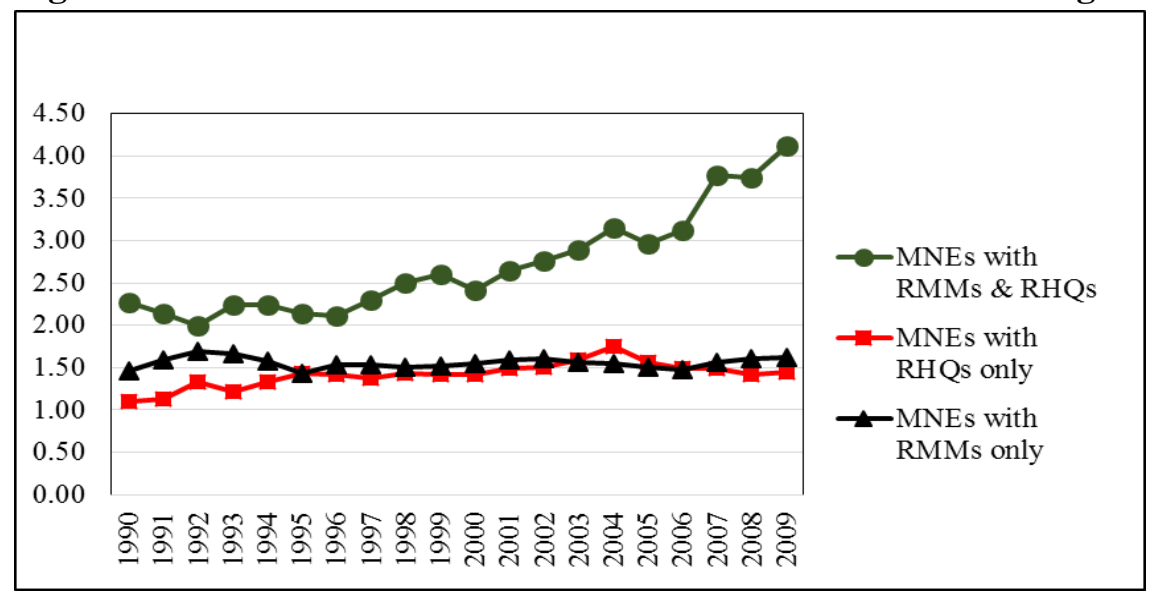


Figure 7 Extended Integration-Responsiveness Framework with Regional Structure-Strategy mapping (adapted from Verbeke \& Asmussen, 2016)

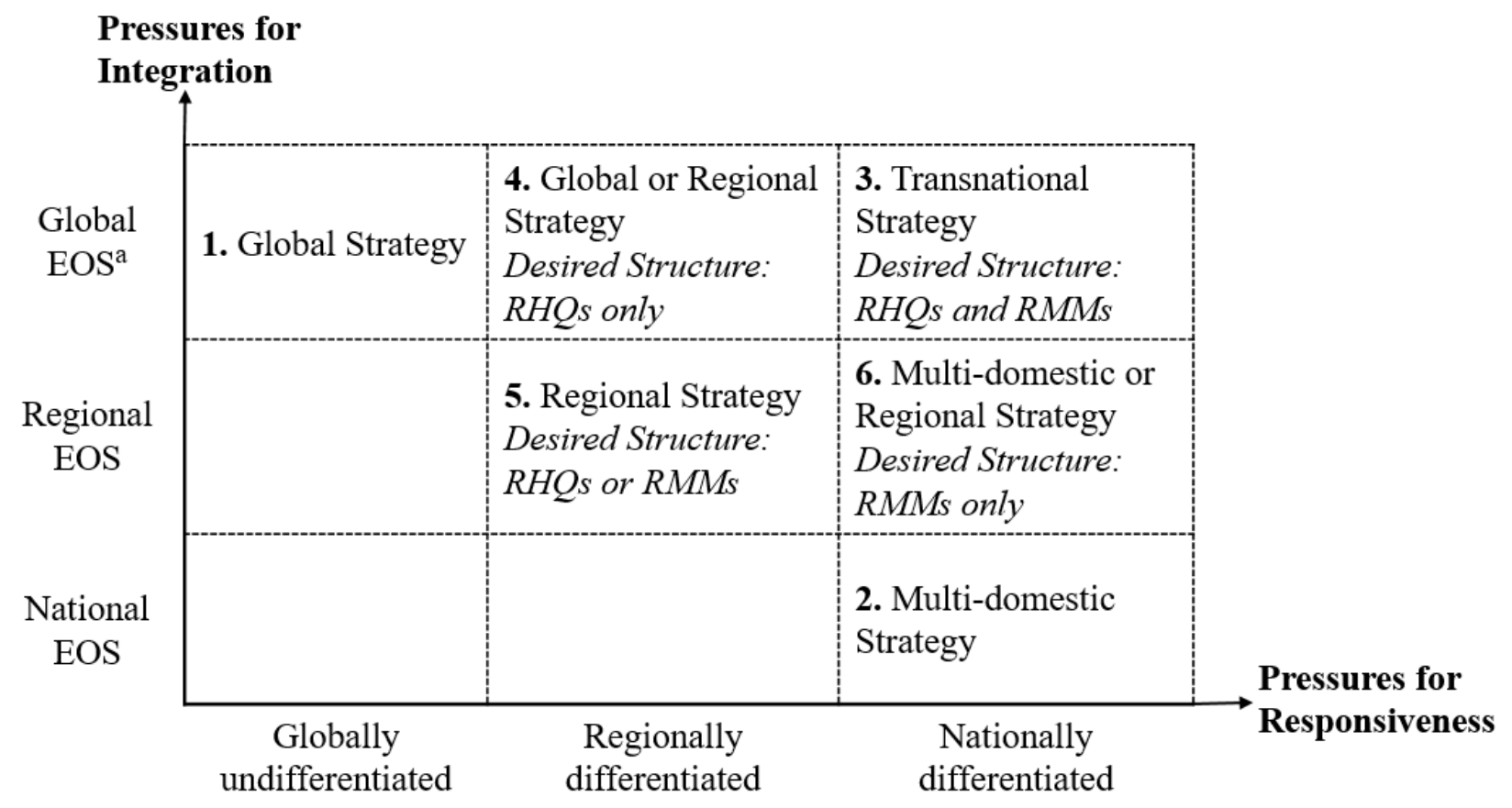

a. EOS: Economies of Scale.

Figure 8 Conceptual Model

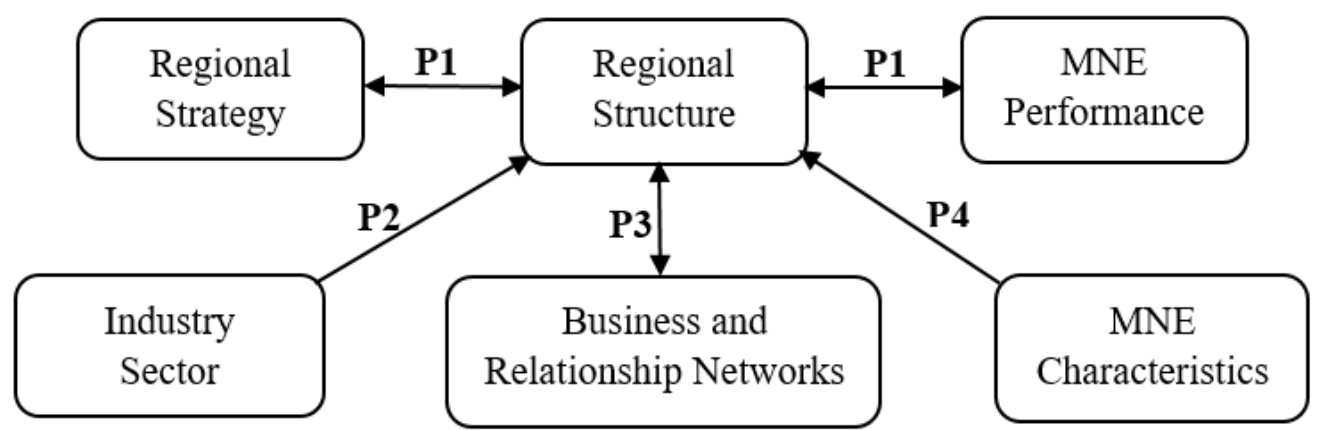




\section{APPENDIX I}

\section{Prior empirical RMC studies in chronological order}

\begin{tabular}{|c|c|c|}
\hline Authors & Approach & Major Arguments \\
\hline Parks, 1969 & Interviews & $\begin{array}{l}\text { RHQs are not effective for U.S. MNEs in Europe because of poor profits, } \\
\text { management, communication, and cultural differences. Guidelines are provided for } \\
\text { effective RHQ strategy. }\end{array}$ \\
\hline $\begin{array}{l}\text { Stopford \& Wells, } \\
1972\end{array}$ & Survey & $\begin{array}{l}\text { MNEs with a high percentage of foreign sales adopt geographical area } \\
\text { configurations, but global product divisions are still popular when product diversity } \\
\text { is high. High percentage of foreign sales and high product diversity predict a matrix } \\
\text { structure. }\end{array}$ \\
\hline Heenan, 1979 & Survey & $\begin{array}{l}\text { Both American and Japanese executives demonstrate preferences for supportive } \\
\text { services, communications and proximity to major country markets. }\end{array}$ \\
\hline Egelhoff, 1988 & Secondary data & $\begin{array}{l}\text { Test of Stopford-Wells' model. Product diversity leads to product divisions, but } \\
\text { foreign sales does not discriminate between area and product divisions. However, } \\
\text { foreign manufacturing leads to area divisions to improve regional coordination. }\end{array}$ \\
\hline Sullivan, 1992 & $\begin{array}{l}\text { Survey and } \\
\text { interviews }\end{array}$ & $\begin{array}{l}\text { Investigated how European RHQs of U.S. MNEs manage the tension between global } \\
\text { standardization and local responsiveness. Found that RHQs do so by mediating } \\
\text { between the formal structure and informal (behavioral) sub-structure. }\end{array}$ \\
\hline Schütte, 1995 & Case study & $\begin{array}{l}\text { Henkel Asia Pacific RHQ was established to "participate in the region's growth” and } \\
\text { aimed to strengthen Henkel's position in the region. }\end{array}$ \\
\hline Lasserre, 1996 & $\begin{array}{l}\text { Informal } \\
\text { interviews }\end{array}$ & $\begin{array}{l}\text { RHQs play different roles as “initiators”, “facilitators”, “coordinators”, and } \\
\text { "administrators” at different stages of MNE internationalization. }\end{array}$ \\
\hline Schütte, 1997 & Secondary data & $\begin{array}{l}\text { Many European MNEs started to expand to Asia in the 1990s through the } \\
\text { establishment of RHQs, which needed to be justified by the MNE developmental } \\
\text { stage, the objectives, the scope of operations, and the regional commitment. }\end{array}$ \\
\hline $\begin{array}{l}\text { Lehrer \& } \\
\text { Asakawa, } 1999\end{array}$ & Interviews & $\begin{array}{l}\text { Strategic importance of the region does not equal an enhanced role for RHQs. } \\
\text { American and Japanese MNCs are "unbundling” their European operations to } \\
\text { enhance flexibility. }\end{array}$ \\
\hline Schlie \& Yip, 2000 & $\begin{array}{l}\text { Survey, interviews, } \\
\text { archival data }\end{array}$ & $\begin{array}{l}\text { Regional strategies emerge at later stages in the evolution of an MNE's global } \\
\text { strategy. RHQs are seen as a means to balance integration and responsiveness. }\end{array}$ \\
\hline $\begin{array}{l}\text { Yeung, Poon \& } \\
\text { Perry, } 2001\end{array}$ & $\begin{array}{l}\text { Survey and } \\
\text { interviews }\end{array}$ & $\begin{array}{l}\text { Geographical distance, strategic necessity, and the availability of business services } \\
\text { influence MNEs’ decisions to establish RHQs in Singapore. }\end{array}$ \\
\hline $\begin{array}{l}\text { Wolf \& Egelhoff, } \\
2002\end{array}$ & Secondary data & $\begin{array}{l}\text { Re-tested Egelhoff's (1988) model, and extended it for matrix structures. Results } \\
\text { suggest that a region-product matrix is more likely with high product diversity, and a } \\
\text { region-functional matrix is more likely for higher levels of foreign manufacturing. }\end{array}$ \\
\hline $\begin{array}{l}\text { Asakawa \& } \\
\text { Lehrer, } 2003\end{array}$ & Case study & $\begin{array}{l}\text { Regional offices play an important role in mobilizing MNE knowledge globally, } \\
\text { especially in the case of the "local-for-global" pattern. }\end{array}$ \\
\hline Paik \& Sohn, 2004 & Case study & $\begin{array}{l}\text { RHQs in several large Japanese MNEs are finding it difficult to achieve global } \\
\text { integration and local responsiveness. Study examines effectiveness of a double-tiered } \\
\text { RHQ scheme (at corporate group and individual business unit level). }\end{array}$ \\
\hline Enright, 2005 (a) & Survey & $\begin{array}{l}\text { RHQs, regional offices, and local offices play distinctive roles in MNE strategies. } \\
\text { The headquarters-subsidiary paradigm needs to be extended to include different } \\
\text { organizational forms. }\end{array}$ \\
\hline Enright, 2005 (b) & Survey & $\begin{array}{l}\text { Firm-specific and location-specific factors influence the roles a regional centre plays. } \\
\text { They also provide guidelines for managers of regional management centres. }\end{array}$ \\
\hline $\begin{array}{l}\text { Ambos, } \\
\text { Schlegelmilch, } \\
\text { Ambos \& Brenner, } \\
2009\end{array}$ & $\begin{array}{l}\text { Case study, } \\
\text { interviews }\end{array}$ & $\begin{array}{l}\text { Evolutionary perspective on regional management. Over time, driven by the need for } \\
\text { legitimacy and influence, an acquired bank head office in Central and Eastern Europe } \\
\text { strengthened its capabilities and transformed its role from regional governance and } \\
\text { standardisation to a regional center of excellence in banking practices. }\end{array}$ \\
\hline $\begin{array}{l}\text { Ambos \& } \\
\text { Schlegelmilch, } \\
2010\end{array}$ & Case studies & $\begin{array}{l}\text { Regionalization strategy helps large MNEs deal with complexity and diversity, and } \\
\text { RHQs are used to achieve superior performance. MNEs define regions based on } \\
\text { activities, industries, and their development stage. }\end{array}$ \\
\hline $\begin{array}{l}\text { Li, Yu \& Seetoo, } \\
2010\end{array}$ & Case study & $\begin{array}{l}\text { Sub-regional HQs are established in response to integration-responsiveness forces. } \\
\text { Industry characteristics and firm-specific advantages (FSAs) affect the delegation of } \\
\text { authority from a parent to RHQs and sub-regional HQs. }\end{array}$ \\
\hline
\end{tabular}




\begin{tabular}{|c|c|c|}
\hline $\begin{array}{l}\text { Piekkari, Nell \& } \\
\text { Ghauri, } 2010\end{array}$ & Case study & $\begin{array}{l}\text { Matching regional management capabilities with information processing } \\
\text { requirements is a complex process of evolution and adaptation. Changes occur at } \\
\text { constituent regional elements, regional, and corporate levels to address the need for } \\
\text { inter-region differentiation, and complexities at various levels. }\end{array}$ \\
\hline $\begin{array}{l}\text { Benito, Lunnen \& } \\
\text { Tomassen, } 2011\end{array}$ & Secondary data & $\begin{array}{l}\text { Greater degree of internationalization does not increase RHQ numbers; rather it is } \\
\text { related diversification which leads to increase in RHQ density. Larger firms have } \\
\text { fewer RHQs. }\end{array}$ \\
\hline $\begin{array}{l}\text { De La Torre, } \\
\text { Esperanca \& } \\
\text { Martinez, } 2011\end{array}$ & Survey & $\begin{array}{l}\text { Market integration forces such as competition and globalization drive structural } \\
\text { efforts at regional coordination and formation of RHQs. Older and larger firms have } \\
\text { more RHQs, but the number of regular subsidiaries is not a predictor of RHQ } \\
\text { numbers. }\end{array}$ \\
\hline $\begin{array}{l}\text { Nell, Ambos \& } \\
\text { Schlegelmilch, } \\
2011\end{array}$ & Case study & $\begin{array}{l}\text { Regional management structures may be difficult to implement, since several MNEs } \\
\text { have trouble allocating decision-making authority to RHQs and grouping subsidiaries } \\
\text { into regions. While RHQs may manage interdependencies within regions well, their } \\
\text { presence cuts off the management of interdependencies between regions. }\end{array}$ \\
\hline Alfoldi et al., 2012 & $\begin{array}{l}\text { Case study and } \\
\text { interviews }\end{array}$ & $\begin{array}{l}\text { Regional mandates for operating subsidiaries is a cost efficient and responsive } \\
\text { alternative to more administratively focused RHQs, especially in smaller peripheral } \\
\text { markets. However, there are risks of legitimacy and of CHQ being blindsided. }\end{array}$ \\
\hline $\begin{array}{l}\text { Mahnke, Ambos, } \\
\text { Nell \& Hobdari, } \\
2012\end{array}$ & Survey & $\begin{array}{l}\text { RHQs' influence on corporate strategy is positively related to their autonomy and } \\
\text { signalling behaviour. In addition, the specific characteristics and extent of a RHQ } \\
\text { mandate moderates this relationship. }\end{array}$ \\
\hline $\begin{array}{l}\text { Edgington \& } \\
\text { Hayter, } 2013\end{array}$ & Interviews & $\begin{array}{l}\text { Singapore is the dominant RHQ centre for Japanese firms operating in the Asian } \\
\text { market. While several decision-making functions have been devolved to RHQ, R\&D } \\
\text { remains centralized and involves HQ engineers working with subsidiaries. }\end{array}$ \\
\hline $\begin{array}{l}\text { Hoenen, Nell \& } \\
\text { Ambos, } 2014\end{array}$ & Survey & $\begin{array}{l}\text { RHQs by being embedded across local, regional, and global markets occupy an } \\
\text { important intermediate position, since HQ is weakly embedded in local markets, } \\
\text { while subsidiaries are strongly embedded locally, but less so regionally and globally. }\end{array}$ \\
\hline Kähäri, 2014 & $\begin{array}{l}\text { Survey and } \\
\text { interviews }\end{array}$ & $\begin{array}{l}\text { RHQs are inherently dynamic and sensitive to change because they are embedded in } \\
\text { local, regional, and global environments. Their role, location, and geographic scope } \\
\text { are interdependent, and change in one attribute will affect other attributes. }\end{array}$ \\
\hline $\begin{array}{l}\text { Lunnan \& Zhao, } \\
2014\end{array}$ & Case study & $\begin{array}{l}\text { An RHQ facilitates MNE knowledge transfer through its management, structure, and } \\
\text { position within the subsidiary network. }\end{array}$ \\
\hline Zhou, 2015 & Secondary data & $\begin{array}{l}\text { Frontline subsidiaries in countries with weaker institutions are more likely to be } \\
\text { supervised by foreign rather than domestic supervisory units. Foreign supervision is } \\
\text { even more likely when subsidiaries in weak-institution countries conduct activities } \\
\text { that are more central to or interdependent with their parents' global operations. }\end{array}$ \\
\hline
\end{tabular}

\section{ENDNOTES}

i Our literature search covered the following journals: Academy of Management Journal, Academy of Management Review, Asia Pacific Journal of Management, Administrative Science Quarterly, European Journal of Management, International Marketing Review, Journal of International Business Studies, Journal of International Management, Journal of Management Studies, Journal of World Business, Long Range Planning, Management International Review, Organization Science, Strategic Management Journal, and Urban Studies.

ii Since the distribution of the number of employees is highly skewed to the left with a long tail to the right, a logarithmic transformation was performed on the data to meet the normality assumption and improve interpretability.

${ }^{\text {iii }}$ For highly skewed variables, a natural logarithm transformation was carried out to get a normalized distribution. At the parent MNE-level, we used the logarithm of operating revenue, number of employees, total assets, R\&D intensity, advertising intensity, and degree of internationalization; at the foreign affiliate-level, we used the logarithm of operating revenue, and number of employees. 